\title{
QUE FRONTEIRAS PARA A UE?
}

\author{
Carminda Cavaco ${ }^{1}$
}

\begin{abstract}
Resumo: Neste artigo discute-se a identidade da Europa, o projecto e o processo da construção europeia, os alargamentos sucessivos e a mobilidade das fronteiras externas, na perspectiva de uma Europa de geometria variável. Desenvolvem-se considerações sobre o 'retorno à Europa' dos PECO, a sua viragem para a democracia, os problemas de inserção numa economia de mercado, os apoios comunitários e as novas dinâmicas de desenvolvimento. Em seguida, encaram-se os novos alargamentos a curto prazo, até ao Adriático e ao mar Negro, com as próximas adesões da Roménia, Bulgária e Croácia. Outras considerações são formuladas acerca da possibilidade de novos alargamentos a médio e longo prazo, com deslocamento das fronteiras externas para leste até à Rússia e ao Cáucaso, em direcção ao Médio Oriente, pela Turquia, e para sul, pelo Norte de África, por países onde se sente um certo 'desejo de Europa'. A UE atrai, como um império pós-moderno, e à Europa importa estabilizar e modernizar as suas periferias, sem adulterar o seu projecto de União, sem prejudicar o aprofundamento do processo de integração.
\end{abstract}

Palavras-chave: Europa, continente, projecto, problemática, alargamentos, novas fronteiras externas, geometrias variáveis.

Abstract: What boRders for the EU? This article addresses the identity of Europe, the project and process of the construction of Europe, the successive enlargements and the mobility of external borders from the perspective of a Europe of variable geometries. It attempts to develop the discourse on the "return to Europe" for the Central and Eastern European Countries (CEEC), their movement towards democracy, their difficulties in entering the global market, EU assistance and new development dynamics. Then, the new enlargements for the short-term up to the Adriatic and the Black Sea, with the next countries to be admitted being Romania, Bulgaria and Croatia. Other notes are made on the possibility of other enlargements in the medium- to long-term, by setting the external borders farther to the East, towards Russia and the Caucasus, and to the Middle East, towards Turkey, and to the South, towards North Africa, countries that have a certain

1 Professora Catedrática da Faculdade de Letras da Universidade de Lisboa. Investigadora do Centro de Estudos Geográficos. E-mail: carminda.cavaco@clix.pt. Manuscrito recebido em Junho de 2004. 


\begin{abstract}
"desire for Europe". The EU attracts with its status of post-modern empire, and it is necessary for Europe to stabilize and modernize its peripheries, without calling into question the EU's project and with prejudice to strengthening the integration process.
\end{abstract}

Key words: Europe, Continental Europe, project, issue, enlargement, new external borders, variable geometries.

Résumé - Quelles frontières Pour L'Union EuropéEnNe ? On discute ce que sont l'identité européenne, son projet et processus de construction, ses élargissements successifs et la mobilité de ses frontières extérieures, dans la perspective d'une Europe de géométrie variable. On considère aussi les problèmes posés par le «retour à l'Europe » des pays de l'Europe centrale et orientale, par leur virage vers la démocratie et leur insertion dans une économie de marché, par les appuis communautaires et les nouvelles dynamiques de développement. On considère ensuite les nouveaux et prochains élargissements jusqu'à l'Adriatique et la Mer Noire, résultants de l'adhésion de la Roumanie, de la Bulgarie et de la Croatie. Puis on considère la possibilité de nouveaux élargissements à moyen ou long terme, qui entraîneraient le déplacement des frontières vers l'Est jusqu'à la Russie, le Caucase et le Proche Orient, via la Turquie, et vers le Sud, via l'Afrique du Nord, où certains pays ressentent comme un "désir d'Europe". L'UE attire en tant qu'empire post-moderne, mais il importe qu'elle stabilise et modernise ses périphéries, sans modifier son projet d'union et sans amoindrir son processus d'intégration.

Mots-clés : Europe, continent, projet, problématique, élargissement, nouvelles frontières extérieures, géométrie variable.

Samuel Huntington (2001) defende que os Estados se organizam por grandes blocos civilizacionais e, dentro destes, segundo círculos concêntricos em redor dos estados-núcleos, de acordo com o seu grau de identificação e de integração. Para lá das áreas civilizacionais as inclusões de estados serão conflituosas e instáveis; e dentro de cada área civilizacional poderão verificar-se certas exclusões, mas estas serão sempre limitadas se encaradas no tempo longo, e explicar-se-ão por razões históricas. No caso da União Europeia (UE), teríamos a França e a Alemanha como estados-núcleos, a Bélgica e a Holanda como o círculo interior mais integrado, a que se seguiria um segundo círculo com os restantes membros da UE15, e um último, composto pela Polónia, Hungria, República Checa, Eslováquia, Bulgária e Roménia (idem, p. 184): união diferenciada, a duas velocidades, com um núcleo duro e um núcleo mais duro dentro deste último, constituído pela França e a Alemanha, e diferentes cooperações/solidariedades reforçadas? Um núcleo, dois anéis e um circulo exterior de estados-parceiros mas não membros?

A limitação da Europa já não pode ser de natureza ideológica e segundo a fronteira do comunismo, após o seu colapso, nem de natureza militar no quadro pós-guerra fria: assim, para HunTINGTON a fronteira oriental da Europa só 
pode assentar em claras diferenças de cultura e deverá coincidir com a fronteira histórica que desde o século IV vem separando os cristãos do Ocidente e os povos muçulmanos e ortodoxos: partindo de norte, passa pelas actuais fronteiras entre a Finlândia e a Rússia, os estados bálticos (Estónia, Letónia e Lituânia) e a Rússia, segue pela parte ocidental da Bielorrússia e da Ucrânia, atravessa a Roménia e continua, ao longo da fronteira que separa a Eslovénia e a Croácia das outras repúblicas, coincidindo com a divisão histórica entre os impérios austro-húngaro e otomano (...). A Europa acaba onde acaba a cristandade ocidental, católica romana e protestante, e começa o islamismo e a ortodoxia (idem, p. 185).

O Tratado de Roma que instituiu a Comunidade Europeia em 1957 precisa, no artigo 237, que todo o estado europeu pode pedir para se tornar membro. Através de sucessivos alargamentos, a UE veio a englobar 25 estados membros, 10 deles tendo sido integrados a 1 de Maio de 2004. No seu conjunto, cobrem uma grande parte do espaço comummente considerado como europeu: o alargamento pela Europa central terá assim permitido refazer os laços culturais e económicos entre Londres, Paris, Roma, Munique, Leipzig, Varsóvia, Praga e Budapeste. Surgem então algumas questões fundamentais. Pode a UE alargar-se para lá da Europa cultural e incluir não apenas a Europa central mas também a Europa oriental, expressão que HunTINGTON reserva para as regiões que se desenvolveram sob a égide da igreja ortodoxa? Tem sentido, já no século XXI, valorizar uma fronteira de raiz religiosa, que separa dois ramos do próprio cristianismo, organizados por Roma e por Constantinopla, e aceitar a sua afirmação quando diz que a identificação da Europa com a cristandade ocidental fornece um critério claro para a admissão de novos membros das organizações ocidentais, considerando desde logo a UE como principal entidade do Ocidente?

Por outro lado, cabe também interrogarmo-nos acerca de questões mais funcionais. Serão os critérios de admissão na UE predominantemente culturais e económicos? Pode a União continuar a alargar-se sem pôr em causa o seu projecto, ou noutros termos, como compatibilizar o alargamento com o aprofundamento da construção europeia? Até onde se estende realmente o espaço europeu e até onde se alargará a UE? Estará a UE a concretizar o sonho do general de Gaulle, de criar uma solidariedade europeia do Atlântico aos Urais, agora que a URSS deu lugar à Rússia e à CEI? Que razões, económicas, identitárias, de soberania nacional e de neutralidade política ou outras, levam alguns estados a não admitir a sua integração plena na UE, casos da Noruega, Islândia e Suíça, mesmo se membros da EEE? Que razões poderão levar a UE a não admitir a possível candidatura de outros, como certos estados dos Balcãs (Sérvia, Macedónia ou Albânia) e alguns que foram antigas repúblicas soviéticas (Bielorrússia, Ucrânia e Moldávia)? Para certos estados candidatos efectivos deve ser dada preferência à integração económica, através da total abertura às trocas comerciais, que tenderá a perder sentido com o avanço da mundialização, em detrimento da abertura de negociações de adesão com vista à sua integração a prazo, como para a Turquia e os países do Norte de África? Que tipos de distâncias aproximam ou afastam realmente os estados vizinhos dos estados membros da UE, civilizacio- 
nais ou de outra natureza? São de admitir novas descontinuidades territoriais no espaço da União, e a que preço? Continua a justificar-se a integração da Grécia na UE, muito mais produto da guerra fria do que do simbolismo da democracia ateniense, do seu papel de berço da civilização clássica e de uma história muito ligada ao Ocidente, bem mais do que a dos sérvios, romenos e búlgaros?

\section{I. «EUROPA, EUROPAS»!}

Europa, um espaço situado a oeste, o Ocidente, o território de poente, visto a partir do Próximo Oriente e da Grécia, e que foi ganhando amplitude para oeste até ao Atlântico, para norte e também para leste até às estepes do Don, pela terra habitada e conhecida; um espaço de democracia (Atenas), humanismo, liberdade e progresso por oposição aos absolutismos persa, otomano e turco e ao despotismo soviético, e um espaço do cristianismo por oposição ao do Islão, mais tarde apenas do catolicismo, largamente coincidente com o do império romano ocidental; Europa, um continente, continuum de terras, mas também a periferia de oeste de um finisterra; um espaço com significados variáveis, fronteiras incertas, estruturas entrecruzadas (LÉvY, 1997: 4), um conceito de geometria variável, mobilizado por instituições como o Conselho da Europa, a OCDE, a CEE, a UEO e a OSCE, ou ainda, um conceito geográfico mais ou menos estável e um produto histórico e geopolítico instável: Europa da cristandade; Europa católica e protestante, contra Europa ortodoxa e o Islão; a Velha Europa e o Novo Mundo; Europa, um patchwork de povos e de pequenas regiões, de línguas, costumes e religiões, com uma trama mais simples e mais ampla de estados que institucionalizam as nações pré-existentes (idem, p. 53).

Até meados do passado século, as nações-estados revelaram-se capazes de impedir deslocações da soberania política para níveis superiores, mesmo se com relações violentas, desse modo contribuindo para a especificidade europeia: as fronteiras geopoliticas dos Estados constituem a malha mais evidente para compreender as diferenciações do espaço europeu (idem, p. 76), mesmo se o processo de unificação económica, social e cultural permanece inacabado e já perturbado pela afirmação de outras escalas de funcionamento, inferiores e superiores ao nível nacional, a europeia/comunitária e a mundial; uma tradição inventada que serve de suporte a uma identidade construída e constantemente posta em causa (Foucher, 1998: 24), uma comunidade, uma inovação e uma utopia (idem, p. 34); Europa no sentido de Europa ocidental (produto geopolítico dos Acordos de Yalta 1945 e da guerra fria, com a divisão da Europa em dois blocos); Europa como fronteira oriental do mundo ocidental, fronteira do mundo euroatlântico, uma província do Ocidente (que inclui os EUA), versus Europa de Leste; um princípio organizador do continente numa base democrática e de modernidade; um espaço em recomposição, o que evoca as mudanças da sua organização no último meio século, analisadas por J. BARROT et al. (2002), e a anterioridade da 'grande mudança' das sociedades tradicionais em sociedades modernas e os processos da sua diferenciação, que fazem da Europa um somatório de múltiplos passados; 
Europa, uma região mundial, com fortes densidades demográfica, económica, cultural e política, numerosos estados-nação, um dos pólos da Tríade, aberto ao mundo e às trocas comerciais e culturais e de notável progresso social na segunda metade do último século...

Europa, um continente, um espaço com continuidade territorial e uma comunidade de destino. Um continente que vai do Atlântico aos Urais e ao Cáucaso e do Árctico ao Mediterrâneo, e que se estende para sudeste, até à fronteira com o Próximo e Médio Oriente, um continente sem limites bem definidos, antes convencionais, a leste e a sudeste. Uma península ou mesmo um cabo, um finisterra da Eurásia avançado para oeste, na expressão de PAUl VALÉRY. Uma extensão de terras temperadas e com forte influência marítima, pela proximidade e pelo recorte do litoral, e ainda pela extensão de terras baixas e pela existência de mares interiores, o Mediterrâneo e o Báltico, percorrida por rios longos, calmos, sem gelo, de fácil navegabilidade, como no ocidente da Rússia e na bacia do Danúbio, e com populações rurais antigas e densas. Um continente que gozava de uma posição de abrigo perante as invasões de leste, reforçada pelas vastas extensões de floresta, mas aberto ao exterior pelo mar e pela cabotagem costeira. Um continente que se prolonga por ilhas, algumas no Mediterrâneo, cedo povoadas por civilizações precocemente evoluídas e com posições estratégicas nas velhas rotas marítimas. Para leste, na Europa continental, plana, dos grandes espaços e das planícies imensas, infindas, de menos de 400 metros, as influências marítimas tornam-se escassas e os Invernos rudes, pela acção do anticiclone siberiano: terras interiores abertas às invasões nómadas, que ameaçavam a Rússia, a Turquia e os Balcãs. Por aqui passava a linha de contacto entre as populações sedentárias e os invasores.

Europa, uma identidade territorial construída ao longo da história por bifurcações importantes, geradoras de diferenciação, pela posição à margem de invasões e impérios e pela formação de um património cultural complexo (LÉVY, 1997: 25). A Europa não apresenta uma identidade eterna, mas uma especificidade criada por uma história complexa, que fez dela uma encruzilhada de inovações e também de invasões, dos povos nómadas da Pérsia, da Ásia central e da Arábia, dos bárbaros germânicos e dos árabes, até à plena ocupação por populações sedentárias com as arroteias da Idade Média. A Europa bifurcou porque resistiu precocemente às invasões, o que foi possivel por a intensidade de ocupação dos seus espaços rurais`, assente na combinação agricultura-pecuária e em colheitas anuais, travar o avanço dos nómadas (...). O que é próprio da Europa incide no limite. $O$ contacto das civilizações rurais com os nómadas não toma a forma duma fronteira franca. O oeste da Rússia, a Ucrânia, a Anatólia constituem largas franjas nas quais a agricultura se espalhou cedo mas com as dificuldades técnicas que então gerava a continentalidade (sistemas extensivos) (idem, p. 37). Para a Europa o contacto com os invasores é delegado para as suas margens orientais onde a agricultura se reduzia a clareiras e a própria extensão das florestas assegurava protecção, enquanto a sul e a oeste dominavam os espaços agricultados e as populações sedentarizadas e densas. 
O pluralismo na organização espacial, a pluralidade de estados, de instituições religiosas, de poderes locais e de contra poderes, pertenças múltiplas, plurais, hierarquias confusas, democratização e desenvolvimento endógeno, não permitiram a afirmação durável de impérios quase à escala do continente (Carlos Magno, Carlos V), os conflitos entre estados com dimensões e poderes próximos traduzindo-se em destruições para vencidos e vencedores e em conquistas modestas e reversíveis a prazo, de que resulta uma relativa estabilidade das fronteiras dos estados na Europa ocidental, nas suas linhas grais. A Europa de leste tinha uma situação mais exposta e vulnerável, com avanços e recuos dos impérios invasores e ocupações transitórias, mesmo se no tempo longo. Ainda nos séculos XIII e XIV as invasões dos mongóis submeteram a Silésia, Morávia, Hungria, Eslovénia, e estenderam-se pelas terras a norte do Mar Negro.

Face aos impérios nómadas impunha-se a organização de outros impérios capazes de os enfrentar, daí resultando o império russo e o otomano, em detrimento da organização plural das sociedades e dos poderes, que estão na base da 'europeização' da Europa (LÉvY, 1997: 40). Vejamos a delimitação convencional, política, da Europa no quadro do império russo, 'natural' da Europa e separado da Ásia, considerada como o deserto dos Tártaros, terra de descoberta e de aventura. Pedro I o Grande, czar de todas as Rússias, pretendeu que a Rússia e os russos fossem vistos como europeus, desenvolvidos, modernos, portadores de progresso e inovação, evidenciando uma vontade política de adesão a uma sociedade em plena mutação, com passagem da agricultura e pastoreio para as actividades comerciais, manufacturas, vida urbana (Barrot et al., 2002: 8). Para isso, nos finais do século XVII mandou edificar São Petersburgo como capital, tomou o Ural como limite e, sobretudo, abriu uma janela para o mar Báltico, e depois também para as terras de sudeste em direcção ao Mar Negro e ao Cáspio. Os seus sucessores impuseram a tutela russa ao conjunto do Cáucaso na primeira metade do século XIX, desse modo reforçando o declínio do império otomano e do império persa, numa frente de confronto entre cristãos e populações islamizadas.

As zonas de maior conflito no espaço europeu coincidem com linhas de fractura histórica desde os romanos: Império Romano do Ocidente versus Império Romano do Oriente, fronteira entre cristianismos ocidental e ortodoxo, fronteiras ou zonas de interface ocidentais das invasões nómadas da Ásia interior (impérios nómadas) e dos impérios de contacto que se formaram como resposta, casos da Rússia e da Turquia, os quais podem levar à organização defensiva de impérios de transição, sempre a oeste, já no coração da Europa: Áustria-Hungria-Norte de Itália; Prússia e o império alemão; esfera de influência soviética pós 1945; confronto de croatas, bósnios, sérvios, húngaros, romenos, alemães, eslovacos, turcos... Tensões e conflitos agravados pela existência de estados sem correspondência com nações e povos sem estado, nem mesmo território, como os judeus e os ciganos, como sublinha LÉVY (1997: 83-89.)

A descentralização a oeste favoreceu o confronto de ideias, a inovação, a Reforma na igreja, a 'europeização' e com ela a invenção da Europa, mesmo 
se as fontes culturais da 'europeidade' são em larga medida herdadas: gregos e romanos; judaísmo e cristianismo. A invenção da Europa é inseparável da figura do intelectual urbano internacionalizado desde a origem graças ao latim, pelas suas leituras, as suas discussões, as suas viagens, as suas propostas alternativas da tradição, do conservadorismo, do dogma religioso, de abertura ao Outro, do direito e da democracia, do conhecimento e da razão, do humano face ao divino, do indivíduo face à comunidade (idem, p. 40). Em síntese, identifica-se um núcleo de maior 'europeidade' e gradientes de intensidade com o afastamento do mesmo e margens difíceis de situar no espaço: poder-se-á dizer que, geograficamente, a Europa tem um começo mas que o seu fim não é determinado: é um espaço aberto. O lugar Europa é também uma área, um conjunto de lugares, de limites fugidios, deslizantes (idem, p. 49).

Europa, um projecto político algo utópico, uma inovação: $O$ último meio século marca uma bifurcação essencial na ideia de Europa: os europeus tentam pela primeira vez institucionalizá-la, criando um quadro político comum (...). Mas esta inovação desenrola-se num contexto geopolítico singular, pois a guerra fria confere à Europa de oeste uma identidade mais ocidental do que europeia: a Europa (...) é então a fronteira oriental da Euroamérica, em contacto directo com a União Soviética (...). A identidade europeia é estruturada na dependência, como um entre dois, enquadrada por duas superpotências (...), uma provincia do Ocidente (Foucher, 1998: 34), o retorno à Europa dos PECO sendo também o retorno da Europa, em substituição do Ocidente.

O projecto europeu visa sobretudo desenvolver a cooperação entre os estados europeus, de uma forma progressiva. É um projecto evolutivo, não estático, não fixado a priori: passagem da Europa dos povos, das pátrias, das nações, dos estados, dos impérios e das lutas fratricidas a uma comunidade de estados de equilíbrios dinâmicos, capaz de evitar conflitos e de promover a paz e o progresso, no pleno respeito dos valores europeus universais, dos direitos do homem, democracia e liberdade, e no da igualdade de direitos dos estados intervenientes; a Europa faz-se ao mesmo tempo que é pensada, não apenas pelos filósofos, mas pelo conjunto dos seus actores. Ela fez-se mesmo, em larga medida, antes e contra todo o projecto de Europa (Lévy, 1997: 252): o método de construção foi assumidamente voluntário, incremental, progressivo, funcional e assente na unanimidade e no consenso, ou pelo menos na maioria.

A CEE, e depois a UE, traduzem os esforços de concretização desse projecto de paz, unidade, integração e segurança, e não apenas uma cooperação para fazer face ao perigo externo; mas exprimem igualmente um projecto de desenvolvimento, bem-estar social e solidariedade, projecção europeia e mundial, uma inversão no caminho da história. No contexto de pós suicídio, repetido, da Europa: a II Grande Guerra terminara com a destruição e a ruína de vencidos e vencedores e provocara, uma vez mais, o declínio da Europa. Os verdadeiros vencedores não foram os estados europeus envolvidos no conflito mas os EUA e a Rússia, cujas estratégias do pós guerra se traduziam respectivamente na afirma- 
ção económica e política a oeste (recompensa pela intervenção na vitória) e na consolidação imperial soviética a leste, reaparecendo de novo a antiga clivagem que opunha o leste e o oeste europeus. Mas o contexto era também o da internacionalização crescente das empresas e dos mercados, mesmo de mundialização, face à qual os estados europeus eram demasiado pequenos, em particular no confronto com as novas potências económicas e militares, afirmadas desde os finais da primeira grande guerra: os EUA, a Rússia e o Japão. A vertente económica tem aliás dominado na construção europeia: grande mercado interno (60\% das trocas são intracomunitárias); moeda única.

A UE não é um simples mercado sem fronteiras, tende antes para a consolidação da sociedade europeia, multidimensional, multicultural e englobante, como sublinham os autores que vimos citando. 'Fazer a Europa' foi antes de mais reconciliar a França e a Alemanha e reconstruir a Europa ocidental no quadro da cooperação intergovernamental, estimulada e sustentada economicamente pelos EUA: Plano Marshall, OECE e NATO, reforçando o seu papel de barreira face à Europa oriental, integrada económica e militarmente no bloco soviético, pelo COMECOM e pelo Pacto de Varsóvia. Mas foi também passar da simples cooperação intergovernamental à integração, iniciada com a CECA para os sectores do carvão e do aço e alargada com o Tratado de Roma e a criação da CEE: uma comunidade económica que visa a livre circulação de mercadorias, pessoas, serviços e capitais; um grande mercado interno protegido da concorrência exterior, completado por diversas políticas comuns sectoriais, regionais e sociais; o alargamento dos campos de intervenção, expresso no Tratado de Maastricht pela UEM, PESC e Justiça e Assuntos Internos, e por último na Constituição Europeia, que integrou a Carta dos Direitos Fundamentais; a adopção de modos de funcionamento que se pretendem democráticos, eficazes e transparentes, tanto mais que se multiplicam os estados membros, através de sucessivos alargamentos, e se acentuam as disparidades internas.

Os grandes objectivos e os grandes desafios da construção da UE podem-se sintetizar em democracia, economia de mercado, respeito pelos direitos humanos, paz e estabilidade, designadamente através da solidariedade dos ricos para com os pobres, facto tanto mais significativo quando no quadro dos estados se manifestam forças políticas desintegradoras a partir das regiões mais ricas, como a Flandres e a Itália do Norte, mesmo se nos dois casos estamos perante países de unidade tardia (1830 no da Bélgica e 1870 no de Itália), ou como a República Checa e a Eslovénia, e mais recentemente com riscos de repetição na Ucrânia.

O projecto europeu é desde o Tratado inicial um projecto solidário, de coesão social e territorial, reforçada com o Acto Único e o Fundo de Coesão, vertente vulnerável quando se alargam o número de estados membros, as populações e as regiões menos desenvolvidas e a economia acusa dificuldades de crescimento. A solidariedade do projecto europeu terá como dimensão, para o período de 2007-2013, e para os principais contribuintes líquidos, o tecto $1 \%$ do RNB, em oposição aos antigos países da coesão e à própria Comissão, que defendem montantes de 1,14\% do RNB: só assim se poderá assegurar a continua- 
ção do processo de convergência, o prosseguimento do apoio às regióes menos desenvolvidas, dos velhos e não apenas dos novos membros, responder aos compromissos assumidos em 2003 quanto à PAC e ao desenvolvimento rural, etc.

A Europa não é nem inevitável nem eterna. Ela não se fará forçosamente cedo ou tarde. Ela é apenas o produto do tempo. Não há aqui determinismo histórico e vários futuros são possíveis/impossíveis, prováveis/improváveis, feitos de segmentos de lógica de evolução e de dois irracionais, o acaso e a margem de liberdade e de vontade humanas (...). Compreender a Europa é aceitar a dialéctica das convergências e das divergências (...). Não é o fim que conta mas o tempo, motor dos possíveis avanços (FoucheR, 1998: 40).

Eduardo Lourenço (Público, 11 de Setembro e 27 de Outubro 2004, adaptados) é todavia bastante crítico: a Europa é um envelope vazio onde cada uma das suas nações ou etnias deposita o relato das suas proezas sem par (...). Nós, europeus e mentores da universalidade agora sem poder, perdemos o sentido do universal. E com ele, o da Europa que tinha nele a sua utopia (...). Desde o fim da segunda guerra mundial que a Europa é uma vaga Grécia entregue a jogos de política local e de retórica (...), a implosão da União Soviética deixou a Europa nua. Habituada a deixar gerir a sorte do mundo pelos dois inimigos gémeos, suicidário continente que somos há mais de um século, acordou desarmado no dia em que o mundo ruiu. E nunca mais se vestiu. Vivemos à sombra da Nato - Natolândia é o nome exacto da Europa enquanto poder ou impoder.

Também JoRge SAMPAIO considera que falta uma visão clara do papel da Europa no mundo, uma visão estratégica que a longo prazo torne o projecto sustentável, pela ambiguidade do estatuto da PESC. Ao deslocar o centro de gravidade da UE, o alargamento aos PECO reforçou as suas dimensões continental e setentrional e criou as condições para o reforço das relações de cooperação com outros países da Europa oriental e com a Federação Russa. Mas o presidente português avança também que se deverão associar directamente países árabes, mediterrâneos e europeus, reinventando a unidade em torno do Mediterrâneo, o mare nostrum.

Europa, um projecto com ou sem fronteiras? A Europa foi criada para pôr fim aos conflitos repetidos que desde 1870 opunham a França à Alemanha e foi sucessivamente alargada de modo a estender a área geográfica da democracia e do respeito pelos direitos humanos, o desenvolvimento económico e o bem- estar das populações e a consolidar a estabilidade e a segurança, questão que se continua a pôr, nomeadamente a sul e sudeste. Não se relevam neste processo de construção quaisquer valores históricos, geográficos, religiosos ou étnicos mas sim de liberdade política e económica, do Estado de Direito, de tolerância e prosperidade. Procura-se também reforçar a posição relativamente ao exterior de cada estado membro e da União no seu todo. É uma Europa que se articula através de parcerias diversas e se aprofunda com geometrias variadas, que exemplificamos com a adesão ao Acordo Schengen ou à moeda única, recusada até agora pela Suécia, Dinamarca e Grã-Bretanha, estados membros da UE15. É nesta perspectiva de paz, democracia, solidariedade e desenvolvimento que se 
enquadra o alargamento aos PECO em 2004, que fez da UE um mercado de mais de 450 milhões de habitantes.

Até 1989, a Europa era a Europa ocidental, em oposição à situada a leste da cortina de ferro. Correspondia a um conjunto de países, entre eles os da UE, com estruturas económicas, sociais e políticas comparáveis e integrando a OCDE. No seguimento do primeiro alargamento, os 9 estados membros reconheciam que a Comunidade estava aberta às outras nações que partilhassem os mesmos ideais e os mesmos objectivos (BEROUd; WEYDERT, 1997: 195). Nos anos 90, após a queda de muro de Berlim, a desintegração da URSS, a difusão da democracia e o fim da guerra fria, que estivera na origem da Comunidade, o Tratado de Maastricht precisa que basta um estado ser europeu para se lhe juntar, na condição de respeitar o acervo comunitário, tanto em termos políticos como económicos: só os estados democráticos, respeitadores dos direitos do homem, das liberdades fundamentais e do estado de direito, podem pertencer à União Europeia. Trata-se de um acervo aliás evolutivo, até pelos riscos de desestabilização e de desagregação e pelos esforços de não diluição da União numa simples zona de comércio livre, uma espécie de império liberal e democrático que se alarga a pedido a partir de fora das periferias, antes de preservação da identidade e do aprofundamento progressivo da mesma, que aliás acentua o fosso entre estados membros e estados candidatos.

No Conselho Europeu de Lisboa, 1992, foi lembrado que a UE combina elementos geográficos, históricos e culturais que, em conjunto, contribuem para a identidade europeia. A sua experiência partilhada de proximidade, de ideias, de valores e de interacção histórica (...), a rever em cada geração sucessiva. Não é possivel nem oportuno estabelecer hoje as fronteiras da UE cujos contornos se constroem com o tempo (...). Desde a origem, a construção europeia é um processo evolutivo auto sustentado não preocupado com os limites geográficos últimos (...), antes em função de critérios exigentes de adesão, com destaque para o critério democrático, como foi precisado no Tratado de Amesterdão (Foucher, 1998: 94).

Autores há que imaginaram uma estrutura bipolar, dominada pela UE e pela CEI, enquanto outros se interrogaram sobre uma Europa do Atlântico ao Pacífico, mesmo se o Extremo-Oriente russo gravita claramente na órbita Ásia-Pacífico, com relações predominantes com a Coreia, China, Japão e EUA, e o Kazaquistão na da China. Os Urais aparecem de certo modo como limites naturais distantes das zonas de influência de oeste e de leste, do Atlântico oriental e do Pacífico ocidental, e a Rússia asiática como um tampão entre a Europa e a Ásia, uma área de descompressão ou de barreira face às grandes densidades de população da Ásia e aos êxodos do mundo islâmico.

A UE tem e terá sempre fronteiras, apesar das pretensões universalistas da sua cultura? Os limites têm pouco sentido no espaço multidimensional da modernidade das redes; os contornos da UE constróem-se com o tempo. De Tânger a Mourmansk, passando por Istambul e Sampetersburgo, descobre-se a grande diversidade das vizinhanças imediatas da União Europeia, a tal ponto que o único elemento comum entre os estados e também as regiões e as cidades tão diferentes 
reside precisamente na interacção que se joga em direcção aos pólos urbanos e estatais atractivos da união (FoucheR, $1998: 85$ ).

Alargar as fronteiras orientais e de sudeste pode proporcionar à UE maior poder na resolução de conflitos, como o do Médio-Oriente. Todavia, estão claramente fixados os requisitos de adesão: cumprimento dos critérios políticos, estabilidade das instituições garantes da democracia e estado de direito, respeito pelos direitos humanos e pelas minorias; cumprimentos dos critérios económicos, através do funcionamento de economias de mercado e da capacidade de suportar o choque da concorrência no Mercado Único; e cumprimento dos critérios jurídicos, pelo respeito pelo acervo comunitário, incluindo a união monetária.

Europa, uma problemática. Muitos especialistas consideram que o recente alargamento aos PECO constitui para a União Europeia «um dos mais importantes desafios desde a sua fundação; antes de mais, pelo vasto número, heterogeneidade e relativo atraso económico dos países envolvidos, mas também pelas condições históricas particulares dos novos aderentes (...), um número de países superior ao que havia admitido nas anteriores quatro fases de alargamento dispersas ao longo de um período temporal lato (...). Também o diferencial médio que se estabelece entre os novos e os actuais membros é nitidamente superior ao que caracterizou os alargamentos precedentes (...), além da elevada dimensão do sector agrícola nos novos membros da UE (...) e do facto de a generalidade das economias dos países aderentes terem conhecido um processo recente de transição para um sistema de economia de mercado (FonTOURA e CRESPO, 2004). Com a integração de 10 novos membros, em 2004, a população da União cresce cerca de $30 \%$, a superfície aumenta à volta de $1 / 3$ mas o PIB apenas $8 \%$. O alargamento de 2004 assenta na inclusão de oito novos estados-membros da Europa central e oriental com um PIB per capita apenas de cerca de 25-30\% do valor correspondente à UE15, e níveis de desenvolvimento económico que lembram o de Portugal aquando da sua adesão.

A entrada de novos países na UEM, num contexto de debilidade da retoma económica na 'Eurolândia' e manutenção das altas taxas de desemprego, acentuará por si só as incertezas e os desafios: entre estes destacamos o da solidariedade e convergência e o de preservar e reforçar a credibilidade do euro e suportar os custos da gradual apreciação da moeda única face ao dólar, e as pressões inflacionistas estimuladas pela subida dos preços do petróleo, sem descurar o controlo da inflação e a promoção de uma política económica adequada a uma conjuntura recessiva. Trata-se, em síntese, de conseguir ao mesmo tempo estimular o crescimento da economia, a estabilidade do euro, o controlo da inflação e a redução das assimetrias de desenvolvimento.

Como vem sendo insistentemente defendido desde os anos 90, o alargamento não deve contrariar o aprofundamento da construção europeia, no qual se releva não apenas a coesão económica mas também a coesão social e territorial, revalorizadas desde o Acto Único. João Cravinho interroga-se (Diário de Notícias, 17 de Maio 2003): Não se revelará suicidária a presente pulsão de alargamento da UE, o mais depressa possível a quase toda a Europa? E acrescenta, 
a União tem de pôr fim à cascata de sucessivos alargamentos, saltando do carrossel a que se tem deixado atrelar, cegamente disparado ao encontro da Eurásia e do Médio Oriente (...). Para concluir: a UE não pode reduzir-se a uma simples organização pan-europeia. É tempo de fazer uma pausa a 27 estados membros. Para assentar em bases realistas e eficazes a sua capacidade de agir a favor da paz, da prosperidade e da solidariedade da Europa. E no Mediterrâneo, também. Mais alargamento para além de 27 será provavelmente menos União. Com efeito, na sua perspectiva, não basta teorizar os futuros alargamentos a partir da discussão de temas como a ausência dos valores europeus, quem poderá partilhar deles e como estabelecer a sua tradução concreta para efeitos de novas adesões (...), sem esquecer as condições necessárias à construção de uma União Europeia politicamente governável segundo modelos que combinem legitimação democrática e eficiência da partilha de soberania.

A solidariedade numa Europa de 25 ou mais estados e com níveis de desenvolvimento bastante desiguais implica a disponibilização de mais fundos - alargamento de 2004 e novos alargamentos, nomeadamente à Croácia, à Roménia e à Bulgária, já em 2007 -, mesmo se alguns membros e regiões antes beneficiárias deixam de o ser: por exemplo, a Espanha não irá continuar a receber os fundos estruturais do passado, pois terá um PIB per capita de 90\% da média UE25, que será mais baixa do que a actual pela simples inclusão de estados mais pobres, tal como sucedera com Portugal, a Grécia e a Alemanha de Leste, muito embora continuem a ter regiões desfavorecidas. A questão é pertinente, como o atestam as posições dos parceiros comunitários relativamente ao orçamento para 2007-2013: redução para apenas $1 \%$ do PIB, como foi acordado para o orçamento de 2005, sugerem os principais contribuintes, ou seja, a Holanda, Suécia, Áustria, Alemanha, França e Reino Unido.

A abertura das negociações com vista a uma futura adesão da Turquia foi recentemente acordada para Outubro de 2005, mas a sua adesão foi admitida desde logo com complexas cláusulas de salvaguarda, derrogações, períodos transitórios e condições especiais para a introdução de determinadas políticas em áreas de grande sensibilidade, como a livre circulação dos trabalhadores (evitar fluxos migratórios para os países mais ricos como a Alemanha, Áustria, Holanda), as despesas com o apoio ao desenvolvimento, a aplicação da PAC, das políticas de desenvolvimento regional e de coesão, e até mesmo o reconhecimento pela Turquia da sua responsabilidade no genocídio arménio dos finais século XIX e primeiros decénios do seguinte. A Turquia foi aliás o primeiro país a pedir a integração na CEE, há 41 anos; assinou um acordo de associação em 1963 que previa uma união aduaneira com livre circulação de produtos e eliminação de direitos alfandegários, traduzida desde 1996 numa parceria privilegiada, e que poderá ser desde já alargada aos novos 10 membros, incluindo Chipre, Ankara continuando a ocupar a parte norte da ilha desde a invasão militar de 1974.

Cabe então recordar as palavras de Foucher (1998: 7): Seríamos ainda europeus se estivéssemos satisfeitos com a march a das coisas, se tudo estivesse estável à nossa volta, se a construção estivesse acabada, o objectivo alcançado, a força autó- 
noma enfim adquirida e controlada, em resumo, se deixássemos de duvidar e de manejar o paradoxo? Todo o acabamento seria fatal para a Europa, e é justamente esta tensão, este projecto sistematicamente posto em causa, este desejo de Europa, esta construção de que se não conhecem os planos finais, que parece ser a única causa válida.

\section{O «RETORNO À EUROPA» DOS PECO}

Durante quarenta anos, a questão das fronteiras da Europa não se pôs. A Comunidade Europeia monopolizava a palavra Europa. Então, as suas fronteiras eram nítidas, delimitando os territórios dos países membros e de alguns outros situados a oeste da cortina de ferro, fronteira de alarme. A outra metade do continente era a 'Europa de Leste', ou mesmo 'o leste', categoria ideológica sem base territorial legítima. Foi preciso que pensadores dissidentes e corajosos em Praga, Varsóvia ou Budapeste, decidam nos anos 80 romper com a geopolítica dominante para que a 'Europa Central' ressurgisse como noção geográfica e começasse a erodir a cortina de ferro. À divisão estratégica e ideológica do continente, opunham a continuidade das pertenças históricas, a fluidez das expressões culturais, a similitude das arquitecturas. Em resumo, basearam a sua luta de emancipação política sobre uma vontade de 'regresso à Europa' (...). A Europa, a verdadeira, era assimilada a um espaço de liberdade (...). E para a Europa, desde a sua origem, todo o Estado europeu pode tornar-se membro da Comunidade (Foucher, 1998: 94).

Após a queda do Muro de Berlim e o desmantelamento do CAEM, desde o início de Janeiro de 1991, fez-se a passagem de alguns países da Europa central e oriental para a economia de mercado, e com ela a sujeição à concorrência, pela qualidade e preços, em detrimento da produção em massa como resposta às encomendas soviéticas. Atraiu-os a liberdade e a vida democrática, os níveis de desenvolvimento económico e social, os padrões de vida e de consumo, as expressões mais visíveis de progresso, em contraste com o colapso das suas economias, a degradação das infra-estruturas, equipamentos e ambiente, a escassez dos investimentos. Note-se que a reunificação alemã teve lugar logo em Outubro de 1990.

A reorientação das trocas comerciais para oeste, para um mercado livre e concorrencial, colocou-os na condição de fornecedores de produtos banais e a bom preço, condição acentuada pela desvalorização das respectivas moedas e pela subcontratação, e acentuou a necessidade de reconversão dos seus sistemas produtivos, claramente obsoletos e pouco competitivos. Tal implicava vultosos investimentos, a privatização das economias, o desenvolvimento da iniciativa privada e das capacidades empresariais, a atracção de IDE e de novas tecnologias, modernização, assistência técnica e formação, facilidades de crédito, e teria reflexos graves no emprego, com aumentos do desemprego tanto mais significativos quanto mais especializado e dependente for o trabalho. Antes as trocas entra as duas Europas faziam-se entre a CEE e o COMECOM e eram pouco significativas: em 1986, apenas 7\% do comércio externo da CE. Poucos 
estados assinaram acordos directos com a UE antes de 1988, se excluirmos os referentes ao aço e aos têxteis: casos da Roménia e Jugoslávia. Com efeito, a Jugoslávia de Tito não integrou a esfera de influência económica e militar soviética e desenvolveu relações especiais com a CEE, traduzidas na assinatura de um acordo de comércio em 1970, que foi completado em 1980 por um acordo de cooperação, assegurando desse modo acesso privilegiado das suas exportações ao mercado comunitário. E a Roménia de Ceausescu discutia persistentemente a sua submissão ao Pacto de Varsóvia e ao grande mercado soviético...

A aproximação comercial à Europa ocidental foi facilitada pela assinatura pelos países do grupo de Visegrado (Cimeira de 1991, que reuniu a Polónia, República Checa, Eslováquia e Hungria), e depois também pela Roménia e Bulgária, de novos acordos de associação, envolvendo o comércio e a cooperação, secundados por apoios financeiros, através dos programas Phare e Tempus: o primeiro foi instituído em 1989 e canaliza a assistência de dezenas de países ocidentais industrializados, no início apenas para a Polónia e a Hungria, depois para a generalidade dos PECO, incluindo a Roménia, a Bulgária, e também para a ex-Jugoslávia; o segundo alargou os seus objectivos à formação científica e técnica. Essa aproximação comercial foi, por outro lado, contemporânea da efectivação do compromisso último de criação do Mercado Único em 1993, assumido alguns anos antes através do Acto Único, e da criação do EEE, associando à UE, em 1992, a quase totalidade dos membros da AECL e desse modo alargando consideravelmente o espaço económico europeu e o correspondente espaço de liberdade das trocas comerciais. O contexto era também o do fim de todos os impérios coloniais e o das negociações do GATT, com vista à liberalização do comércio à escala global. Depressa as trocas mudaram de composição: dos PECO a UE passou a receber, sem quaisquer restrições contingentais, matérias-primas, combustíveis e produtos de base como aço, mas também plásticos, enquanto nas suas exportações se destacavam produtos com elevado valor acrescentado, como material de transporte, produtos químicos, bens manufacturados.

Entre a Cimeira de 1991 e a de Copenhaga, em Junho de 2003, que fixou Maio de 2004 para o alargamento a 10 candidatos da Europa central e de leste e do Mediterrâneo, decorreram mais de dez anos, que foram anos de discussão e ponderação das vantagens e dos riscos da possível integração para estes e para a própria UE: reforço da democracia, estabilidade política, assimetrias económicas, sociais e territoriais, volume das ajudas de pré-adesão e para as políticas sectoriais, como a PAC, e de solidariedade social e territorial. No conjunto dos 12 candidatos que se perfilavam, destacavam-se os países com baixo rendimento per capita: apenas em Chipre, Malta, Eslovénia e República Checa este se aproxima da média europeia, enquanto nos restantes os valores correspondentes não alcançam 40\%, particularmente na Bulgária, Roménia, Estados Bálticos e mesmo na Polónia. Destacavam-se, por outro lado, os países que apresentavam economias ainda com elevado peso do sector primário, como a Polónia, a Roménia e a Bulgária, com a correspondente pressão no funcionamento e nos custos da PAC. Sem esquecer os problemas previsíveis do funcionamento duma União de 
25 a 27 ou mais países com diferente peso demográfico e diferentes línguas e os de equilíbrio na sua representatividade e na capacidade de influenciar o curso da História da Europa, através dos votos nos Conselhos europeus e no Parlamento Europeu, do número de deputados e de comissários e dos pelouros dos últimos, o que levou ao Tratado de Nice e à Constituição Europeia, aprovada em Roma nos finais de 2004. A estabilidade da viragem política e económica na Europa oriental constituiu um factor de peso na resposta que foi dada pela UE, num compromisso entre aprofundamento e alargamento, constantemente relembrado e discutido: a União é o quadro original duma permanência renovada das nações, sem nacionalismos dominantes (Foucher, 1998: 41). A resposta da União a este grande alargamento foi, todavia, uma resposta prudente, na base de períodos de transição bastante longos, no mínimo de uma dezena de anos, como aliás já sucedera com a dos estados mediterrâneos, também eles na altura pouco desenvolvidos em comparação com os restantes estados membros.

O alargamento de 2004 integrou 10 novos estados: dois pequenos países insulares da Europa do Sul, Chipre e Malta; três pequenos países do Báltico, Estónia, Lituânia e Letónia; e cinco países da Europa central e de leste, Polónia, República Checa, Eslováquia, Hungria e Eslovénia, de dimensão média a grande em termos de população, de nível de desenvolvimento económico muito baixo ou médio, nalguns casos com estruturas económicas com forte representação do sector agrícola, quanto a produção e mais ainda ao emprego da população activa, destacadamente na Polónia. Tal facto ganha relevo quando se tem em conta que a Cimeira de Copenhaga de 2002 conferiu aos novos aderentes um conjunto de medidas de apoio, tal como o acesso imediato aos sistemas de preços e mercados agrícolas em vigor, quotas de produção nos produtos que a elas estão sujeitas na UE, possibilidade de utilização de fundos destinados ao desenvolvimento rural, etc., além de medidas de ordem estrutural, nomeadamente co-financiamento a $80 \%$ para a reforma dos trabalhadores agrícolas, florestação de terras aráveis, medidas agro-ambientais, assistência técnica, etc. (Jacinto NunEs, in Fontoura e CRESPo, 2004: 5). Sem esquecer, todavia, que em 2003 se procedeu à reforma intercalar da PAC no que concerne ao processo de desligamento de ajudas à produção, que foram assumidos compromissos de controlo dos gastos com o sector para o período de 2007-2013 e que prosseguem as negociações no sentido de uma maior liberalização do comércio de bens agrícolas, no quadro da Organização Mundial do Comércio.

Do mar Báltico ao mar Negro, estende-se a Europa média ou central-oriental e a danubiana, espaço de diversidade cultural e religiosa e não menos geográfica e económica, que abarca a Polónia, a República Checa, a Eslováquia, a Hungria, a Roménia e a Bulgária: os três primeiros países e o último, de cultura eslava, os romenos, do grupo latino; os polacos, os checos, os eslovacos e os húngaros, católicos, e os romenos e os búlgaros, ortodoxos; no conjunto, grandes mudanças políticas, e de fronteiras ao longo da História, mas uma mesma ligação à URSS durante meio século, afastamento quase simultâneo nos anos 90 e viragem para oeste, que conduziu a pedidos de integração na UE, a negociações de 
adesão, terminadas e em curso, e ao desviar para leste das suas fronteiras, as novas fronteiras externas confinando com a Bielo-Rússia, a Ucrânia, a Moldávia e a própria Rússia.

Vista de Berlim, a $80 \mathrm{~km}$ da fronteira Oder-Neisse, a Europa central é um mercado privilegiado mas não exclusivo (...), uma área de subcontratação industrial de mão de obra qualificada e um conjunto de estados a incluir logo que possível, mas a um custo negociado e partilhado com os outros Estados-membros, na União Europeia, por razões essenciais de segurança (...). O horizonte de segurança, para a Alemanha (...) está na fronteira oriental da Polónia, limite externo da Europa política desde o início do século, sem dúvida por muito tempo (Foucher, 1998: 89-90), uma vez ratificada, em 1991, a fronteira definitiva com a Polónia, uma fronteira que separa espaços com níveis e dinâmicas de desenvolvimento muito desiguais, em desfavor das regiões de leste, apesar das potencialidades da localização relativa e de apoios para programas específicos referentes a regiões transfronteiriças, das fronteiras internas e externas.

Quadro I - Indicadores referentes a 2001: países candidatos.

Table 1 - 2001 Indicators: candidate countries.

\begin{tabular}{lccccc}
\hline & $\begin{array}{c}\text { Superfície } \\
\mathrm{km}^{2} \\
1000\end{array}$ & $\begin{array}{c}\text { População } \\
\text { milhões } \\
\text { habitantes }\end{array}$ & $\begin{array}{c}\text { PIB/hab. } \\
\text { UE-100 }\end{array}$ & $\begin{array}{c}\text { Agricultura } \\
\text { VAB }\end{array}$ & $\begin{array}{c}\text { Agricultura } \\
\text { Emprego }\end{array}$ \\
\hline Bulgária & 111 & 7,9 & 28 & 13,8 & 26,9 \\
Chipre & 9 & 0,8 & 80 & 3,9 & 4,9 \\
República Checa & 79 & 10,2 & 57 & 4,2 & 4,6 \\
Estónia & 45 & 1,4 & 42 & 5,8 & 7,1 \\
Hungria & 93 & 10,2 & 51 & $4,3(2)$ & 6,1 \\
Letónia & 65 & 2,4 & 33 & 4,7 & 15,1 \\
Lituânia & 65 & 3,5 & 38 & 7 & 16,5 \\
Malta & 0,3 & 0,4 & $55(1)$ & 2,4 & 2,2 \\
Polónia & 313 & 38,6 & 40 & 3,4 & 19,2 \\
Roménia & 238 & 22,4 & 25 & 14,6 & 44,4 \\
Eslováquia & 49 & 5,4 & 48 & 4,6 & 6,3 \\
Eslovénia & 20 & 2 & 69 & 3,1 & 9,9 \\
Turquia & 775 & 68,6 & 22 & 12,1 & 35,4 \\
\hline
\end{tabular}

FonTE: Eurostat (1) 1999; (2) 2000. 
Quadro II - IDE nos PECO, por país de origem e sectores: stock acumulado (\%) 1990-2000.

Table II - Foreign Direct Investment in PECO, by country and sectors: accumulated stock (\%) 1990-2000.

\begin{tabular}{lrlrlr}
\hline \multicolumn{1}{c}{ País } & Stock & \multicolumn{1}{c}{ 1. $^{\circ}$ investidor } & Stock & Actividades económicas & Stock \\
\hline Polónia & 32,0 & Alemanha & 18 & ind. manufactureira & 14 \\
República Checa & 21,8 & Holanda & 12 & agrolimentar & 11 \\
Hungria & 21,0 & Áustria & 7 & elect., gás, água, minas & 7 \\
Roménia & 6,3 & França & 6 & mecânica & 5 \\
Eslováquia & 3,5 & Reino Unido & 6 & química & 4 \\
Lituânia & 3,4 & outros UE & 11 & automóvel & 4 \\
Estónia & 3,2 & outra Europa & 6 & comércio & 12 \\
Bulgária & 3,1 & EUA & 16 & financeiro & 11 \\
Eslovénia & 2,9 & P. Europa Central & 3 & transp., comunicações & 9 \\
Letónia & 2,6 & outros & 15 & outros & 33 \\
\hline
\end{tabular}

FonTE: Laurent Carroué, 2002: 78.

\section{UMA UNIÃO ATÉ AOS MARES ADRIÁTICO E NEGRO?}

A UE é um processo de convergência política e para M. Foucher (1998: 97), nos próximos decénios não é muito realista pensar que a União, construída com base num investimento político de mais de 40 anos, tenha vocação para coincidir, no fim, com a totalidade do continente, a UE tornando-se sinónimo de continente, uma noção geográfica banal, sem conteúdo histórico e geopolítico, que pelo contrário constitui a essência da integração europeia. Nestes aspectos últimos não são menos importantes as relações euro mediterrâneas e com elas a complexidade balcânica: espaços tardiamente rurais e largamente camponeses sem estados-nação estáveis e antigos, sem identidades culturais e territoriais, sem coincidência entre fronteira e identidade e até mesmo sem a consolidação dos princípios mais gerais de democracia.

A UE com 25 e em breve com 27 ou 28 estados membros, se admitirmos a integração a curto prazo também da Croácia, faz fronteira com estados que continuam a gravitar na órbita da Rússia, e da CEI, nomeadamente a Bielorússia mas também a Ucrânia e o Cáucaso, a originalidade russa residindo no facto de não ser nem europeia nem asiática, mas uma ponte entre os dois continentes. Ainda segundo M. Foucher (1998: 104), se a segurança e o controlo migratório, o grau de aprofundamento democrático e o nível de modernização económica são claramente os critérios objectivos para fixar as fronteiras da União para os próximos anos, outros factores relacionais se desenvolvem à escala continental. 
Formou-se um espaço de trocas muito alargado, a União sendo o primeiro parceiro económico da quase totalidade dos estados do continente. Mas também o é para os países das margens leste e sul do Mediterrâneo, muitas vezes com mais de metade do total das trocas de cada país, e com os quais a União Europeia desenvolve projectos que apoia, como o Meda, importando-lhe a estabilidade política e social, o desenvolvimento regional e local, a sustentabilidade ambiental, a segurança, e não apenas as ligações comerciais.

Serão possíveis e aconselháveis novos alargamentos da UE, tendo em conta certas tentações centrífugas que se verificam na CEI, nomeadamente nas margens ocidentais, em que vivem populações com forte 'desejo' de Europa, de democracia e de progresso? Pode a UE vir a integrar estados islâmicos da margem sul e oriental do Mediterrâneo? Como precisava Romano Prodi, em 1999, Quais são as fronteiras, qual é a 'alma' da Europa? No fundo, como sugere Foucher (1998: 112), não será de insistir menos nas fronteiras finais da Europa política que sobre as interdependências: respeito das fronteiras e tratados de vizinhança mas também progressividade das práticas de integração, concentrando-se mais sobre os processos de aproximação que sobre hipotéticos limites últimos (...). A geografia da Europa está na sua política, quer dizer no que os Europeus decidam fazer, de forma realista. Mas não esqueçamos, a Europa é o continente da dúvida e da crítica sistemáticas, dúvida quanto à natureza e o alcance do projecto de União e dúvida quanto aos seus limites espaciais. São aliás múltiplas e diversas as visões da Europa.

\section{Os futuros estados membros do sudeste europeu}

Os limites do projecto de integração continuam indefinidos, nomeadamente nos Balcãs. A UE aceitou e aceitará milhões de muçulmanos e incluirá até países muçulmanos, como a Bósnia ou a Albânia - e talvez a Turquia - porque não policia as crenças. Para Pacheco Pereira há um problema com o Islão, não com a fé do Islão mas com o Islão real, histórico, actual, dos nossos dias, mesmo se no caso da candidatura da Turquia quase todos evitam falar do Islão. São problemas bem mais políticos do que religiosos... Entretanto prosseguem as negociações com vista à adesão da Bulgária e da Roménia, estando prevista a sua integração em 2007. Trata-se de estados que ocupam uma posição na encruzilhada das rotas que unem o sul da Europa centro-oriental e o oeste asiático; de estados que são já membros da NATO, o que alargou o flanco aliado para sul-sudeste, por se localizarem próximo de regiões de crise declarada ou latente, onde podem ter um importante papel estabilizador, designadamente nos Balcãs; e de estados que foram potencialmente aceites como candidatos a admitir na UE ao mesmo tempo que outros que a integram desde Maio de 2004.

Muitos autores distinguem a Europa centro-oriental e danubiana dos Balcãs, por ser mais continental e por ter estado estreitamente ligada à URSS, enquanto os Balcãs são considerados mediterrâneos, tanto pelo clima, embora influenciado pelo relevo, como também pelas suas estruturas, por certas formas de economia 
agrária, pelos aspectos do seu subdesenvolvimento, pelas relações humanas. Os Balcãs são também, na opinião de Joaquín Bosque MAUReL, um espaço novo a que um complexo passado secular havia imposto e imprimido várias influências, quer mediterrâneas - pelos romanos - quer orientais - pelos turcos - quer também centro-europeias - pelos germânicos - quer ainda pelos eslavos russos. Deste modo, a uniformidade e a variedade caracterizam este espaço, tradicionalmente rural, com fortes marcas do domínio turco e com percursos socialistas mas independentes da URSS.

A Roménia situa-se toda ela na Europa danubiana e ocupa os antigos Estados da Moldávia e da Valáquia, após a emancipação relativamente aos húngaros no século XIV; desde o século XV fez-se sentir o perigo crescente do império otomano, acabando por ficar submetida à sua influência, assim como a invasões frequentes entre os séculos XVI e XIX pela Rússia, Áustria, Hungria. A independência total em relação a Constantinopla só foi conseguida em 1877. A seguir à primeira guerra mundial a Roménia anexou grande parte da Transilvânia, à custa da Hungria. Em 1947, tornou-se numa república comunista, mantendo todavia algum distanciamento em relação a Moscovo, traduzido nas trocas comerciais com espaços económicos não comunistas, nomeadamente com a Europa ocidental: exportação de cereais, em particular trigo, cevada e milho, e de madeiras, pois dispõe de apreciáveis reservas, quase tanto como a Polónia, o maior produtor da Europa oriental se exceptuarmos a União Soviética; exportação também de crude.

A Roménia ocupa $237 \mathrm{mil} \mathrm{km}^{2}$, o dobro da superfície da vizinha Bulgária. A sua área só foi consolidada em 1918: cerca de 1/3 é montanhosa, os Cárpatos alcançando 2.544 metros; outro terço são mesetas, planaltos mais ou menos elevados, como na Transilvânia e na Moldávia; e o restante, são planícies baixas. Os climas vão desde o Mediterrâneo, junto do Mar Negro, ao continental, com o rigor dos seus Invernos e os acentuados contrastes térmicos anuais, e aos climas alpinos nas partes altas dos Cárpatos; e a cobertura vegetal, das estepes da Moldávia, onde as precipitações são escassas, aos prados alpinos nas terras altas, passando pelo andar inferior de azinheiras, seguido pelo de coníferas e faias. A Roménia conta cerca de 23 milhões de habitantes, com minorias de húngaros, alemães, ciganos, ucranianos, sérvios, hebreus, tártaros, russos. O cristianismo ortodoxo é a religião largamente dominante. A língua é o romeno, a única de origem latina na Europa oriental, embora com muitas influências dos gregos, magiares, germânicos, eslavos e turcos. A cultura tem uma forte componente latina.

A economia da Roménia manteve uma acentuada componente agrícola, tanto em termos de superfície cultivada como de população rural, não obstante a política de concentração da mesma em centros agro-industriais promovida por Ceausescu, desde os meados dos anos 80, o que levou ao abandono de muitas aldeias, sobretudo nas zonas com minorias húngaras e alemãs da Transilvânia, e de todo o processo de reforma agrária. Iniciada em 1945 com expropriação dos latifúndios e a sua repartição pelos pequenos agricultores sem terra ou com 
menos de 5 hectares, reservando todavia parte da terra para a criação de grandes explorações estatais, de experimentação e difusão de apoio técnico, a reforma agrária romena, como tantas outras, deu lugar, nos finais de anos 60 , à colectivização e implantação de um novo modelo, o de cooperativas de produção, produzindo por contrato com o Estado, que recebia as colheitas, fornecia os factores de produção, promovia a mecanização e concedia crédito nos períodos difíceis. A inserção nas cooperativas foi obrigatória, anulando-se os direitos privados individuais sobre a terra que tinham sido concedidos pela primeira reforma. Para além da mecanização houve intensificação e diversificação dos sistemas de produção, com destaque para a vinha, as hortofrutícolas e a pecuária (forragens, pastos e pastagens; bovinos, ovinos e porcinos), não apagando no entanto muitos traços de uma agricultura arcaica e tradicional, com domínio de culturas extensivas e baixo nível técnico. Retenhamos que a Roménia é um produtor de vinho com que terão de rivalizar outros estados membros, como Portugal, a Grécia, a França, a Itália, a Hungria e a Bulgária.

Mas a Roménia também é um país industrial. Desde logo porque dispõe de importantes fontes de energia, como carvão, petróleo, gás metano, e de energia eléctrica de origem hidráulica, assim como de algum ferro, manganésio, chumbo, sal-gema. Depois, porque desenvolveu complexos siderúrgicos (aço e laminados), metalúrgicos (cobre e chumbo), mecânicos (tractores, automóveis, máquinas eléctricas, construção naval), químicos, associados ao petróleo e gás e ao sal-gema (fibras sintéticas, fertilizantes, corantes, detergentes...). Na produção industrial relevam-se ainda o sector têxtil (fios de algodão e lã, tecidos), o calçado, as porcelanas e os ramos alimentares, muito embora tenha sido dada preferência nos primeiros planos quinquenais à indústria pesada e só depois aos ramos orientados para o consumo. O turismo também constituiu um sector com algum peso nas economias regionais, como nos Cárpatos, com as suas estações de montanha frequentadas todo o ano, e junto do Mar Negro, onde foram desenvolvidas estâncias de turismo litoral, de sol e mar, e outrora de vilegiatura e climatismo invernal.

A Bulgária, a sul da Roménia, entre a planície do Danúbio a norte e a Turquia e a Grécia, a sueste e sul, ocupa cerca de 111 mil km² e tem uma população de 9 milhões, mais de $90 \%$ búlgara, de origem eslava ou turco-mongol, tendo sido assimilados cultural e linguisticamente pelos eslavos, e algumas minorias étnicas (turcos, os mais numerosos, ciganos, pomak, ou búlgaros islamizados, e também arménios, romenos e gregos), em relação com a posição geográfica e a história do país: colónias gregas no litoral; ocupação romana; ocupação por tribos eslavas e turco-mongóis desafiando Bizâncio; feudalização e domínio de Bizâncio, nos séculos XI e XII; e invasão otomana nos finais do século XIV, que durou até à independência e se traduziu por uma forte orientalização da parte leste do país, a Trácia e a costa do Mar Negro. A ocupação turca dominou durante cinco séculos, a libertação do império otomano e a conquista da independência tendo lugar só em 1878 e em associação com a Roménia, separando-se desta em 1908. Nos finais da segunda guerra mundial (1947) a Bulgária foi também ela integrada na área de influência da União Soviética. 
Na sua geografia, destacam-se a plataforma danubiana, planície de sopé dos Balcãs até à fronteira com a Roménia; os Balcãs, arco montanhoso que não ultrapassa 2.400 metros, alpino como os Cárpatos; os Rhodopes, a sul, junto da fronteira grega, e que se elevam a quase 3.000 metros, as altitudes mais elevadas da península; as planícies entre ambos, que se estendem até à da Trácia, junto do Mar Negro. Do ponto de vista climático sobressaem as características continentais, com os seus invernos longos e frios e os verões muito quentes e secos, a escassez das chuvas e a sua concentração na primavera-verão. Acresce a diferenciação imposta pelo relevo, no sentido de diminuição das temperaturas e aumento da pluviosidade, que nos cimos mais elevados se aproxima dos $2.000 \mathrm{~mm}$ por ano, e ainda a dominante mediterrânea na parte sul, protegida pelo sistema montanhoso das influências continentais. Associado a estes climas temos, por um lado, turismo de montanha nos Rhodopes e por outro, turismo de sol e mar junto do Mar Negro.

A Bulgária é um país habitualmente considerado como agrícola, rural e tradicional, onde persiste uma pequena agricultura camponesa de subsistência, com subemprego e desemprego oculto generalizados. Tal como a Roménia, experimentou a reforma agrária colectivista, assim como transferências de população rural para a indústria pesada e processos de urbanização acelerada do território, após a II Grande Guerra e a implantação do socialismo. A modernização agrícola começou com o emparcelamento cooperativo, acompanhado por obras de regadio, para dar lugar à concentração em cooperativas de produção, de modo a tornar mais fácil a difusão não só do regadio como de todo o progresso técnico, seja mecânico, químico ou biológico, e a intensificação dos sistemas produtivos. A seguir a 1970, e através da concentração das cooperativas, são criados vastos complexos, de dezenas de milhares de ha, que incorporam as indústrias agro-alimentares e integram nalguns casos centros de investigação agro-pecuária. Nas produções da Bulgária relevam-se os cereais (trigo e milho, e mesmo arroz), culturas industriais para exportação, como tabaco, algodão, rosas (o principal centro mundial de extracção desta essência), girassol, tomate, hortícolas, batata, morangos, vinhos com renome nos mercados internacionais, sem esquecer a criação de gado, com destaque para os rebanhos de ovinos, tradicionalmente transumantes, mas também para a criação de bovinos e suínos, de cunho industrial. Nas exportações, o tabaco, os cereais ou o vinho acompanham os metais ferrosos ou as máquinas eléctricas.

Até meados do século passado, apenas se destacavam as indústrias associadas ao têxtil e ao sector alimentar. Com a inserção na esfera da URSS e no COMECON e os vultosos investimentos russos, o processo de industrialização ganhou fôlego, de início orientado para a indústria pesada, designadamente maquinaria agrícola, depois diversificando as estruturas produtivas e valorizando os recursos disponíveis e em seguida, nos anos oitenta, procurando a modernização dos processos e a melhoria da produtividade. O país conta com hulha, algum petróleo, gás natural, urânio, chumbo e zinco, cobre, produção de electricidade em centrais termoeléctricas e nuclear e sistemas hidroeléctricos, 
e desenvolveu complexos siderúrgicos e metalúrgicos, químicos e mecânicos. A produção industrial foi assim muito diversificada, juntando uma oferta nova à oferta tradicional do têxtil, couros, papel e produtos alimentares. As trocas comerciais no início dos anos 90 faziam-se essencialmente com a União Soviética e, à distância, com a Alemanha e a Polónia.

\section{Os estados balcânicos ocidentais, membros potenciais da UE}

A Eslovénia integrou a UE em 2004 e a Croácia prepara a sua próxima adesão, pelo cumprimento dos critérios básicos, provavelmente ainda em 2007, com a Roménia e a Bulgária, ou nos anos imediatos, pelo atraso na introdução de reformas de adaptação ao acervo comunitário e ao mercado, o que implica o fim das subvenções das empresas públicas distorsoras da concorrência e tem impactos económicos e no emprego dos sectores mais sensíveis. E os outros estados balcânicos? Entretanto, a Macedónia, a Sérvia e a Bósnia e a própria Albânia permanecem em situação política instável. A estabilidade e o desenvolvimento de uma vasta área geográfica, da Bósnia ao Cáucaso e ao Médio Oriente, dependem ou não da sua inclusão política na família europeia? A UE partilha com os países balcânicos, a história, muitos valores, o cristianismo, a separação do poder, da fé e do saber, a responsabilidade na resolução de conflitos, como na Bósnia, na Sérvia, no Kosovo (província integrada na Sérvia-Montenegro, administrada pela ONU desde meados de 1999 e de maioria albanesa), na Albânia e na Macedónia. Nestes países afloraram dramaticamente, nos anos 90, ideologias etno-nacionalistas e identidades tradicionalistas e arcaicas, geradoras de crises repetidas, relativamente às quais foi preciso intervir em termos diplomáticos, militares e económicos, nomeadamente através de acordos de associação e de estabilização. De qualquer modo, as fronteiras destes estados são recentes e políticas, derivam sobretudo da desagregação dos impérios austro-húngaro e otomano e da retirada turca nos primeiros decénios do século XX.

Os Balcãs ocidentais correspondem ao território da ex-Jugoslávia, federação de repúblicas de unidade tardia, apenas de 1919, após desmembramento do império austro-húngaro e do turco, e que agrupara os Eslovenos, os Sérvios, os Croatas e várias minorias. Foi uma integração que registou processos de desintegração nos anos 30 e que após a II Grande Guerra deu lugar a uma república federativa e socialista, a qual permaneceu fora da órbita de Moscovo e desenvolveu relações privilegiadas com os países da Europa Ocidental. Corresponde a uma área que fora unida apenas durante o império romano e atravessada ao longo da História por várias fronteiras e suas turbulências, que estão na origem das suas muitas fragilidades, da sua diversidade, das deslocações e misturas das populações, do seu pluralismo e dos diferentes graus de 'europeidade', muito mais forte nos espaços da Eslovénia e da Croácia, como nota J. Lévy (1997: 96): fronteira entre os impérios romanos de ocidente e de oriente e entre os católicos e os ortodoxos; fronteiras do império austríaco, que possuiu a Eslovénia, do território da República de Veneza e da Hungria, o que significa limite das 
respectivas zonas de influência, periferias; travessia pelas frentes de avanço dos impérios conquistadores, caso do império otomano; ocupação turca prolongada, mas também ela periférica, e no seu seguimento, presença de uma comunidade muçulmana laica e autóctone, que complica ainda mais a paisagem religiosa; projectos de construção e afirmação de estados geradores de conflitos, nomeadamente por parte da Sérvia.

Os Balcãs contêm uma mistura de povos que habitaram a península, o Peloponeso, a Macedónia, a Trácia, a Anatólia e as ilhas que hoje são da Grécia e da Turquia. Por aqui encontramos aproximadamente os mesmos grupos étnicos de base, perturbados por acidentes históricos que ora os dividiram e ora os uniram, mas que hoje apresentam diferenças culturais acentuadas e usam línguas oficiais que os demarcam, além da religião. Um verdadeiro mosaico étnico, e também religioso, lembra Francisco Belard (Expresso, 30 de Outubro 2004, adaptado). São também grandes as disparidades económicas regionais, herdadas e agravadas pelos conflitos. Compreende-se facilmente, por tudo isso, a posição do ministro dos Negócios Estrangeiros da Albânia, na 43. a sessão da Assembleia Geral da NATO, em 1988: A desestabilização de qualquer dos países balcânicos redunda em prejuízo dos restantes... Um dos problemas mais agudos é o das nacionalidades e das minorias que habitam nos territórios de uns e de outros. Ao tratar-se deste problema é preciso agir sem paixão, com prudência política e com justiça (...). Quando as minorias e as nacionalidades gozam de todos os direitos sem discriminações, transformam-se em factores de coesão no interior do país e em elementos de aproximação e de amizade entre os povos e os países...

Espaço marcado por uma História com múltiplas heranças, misturas de povos, mas também de culturas e religióes, que potenciavam uma sociedade heterogénea e pluralista. Assim, a Bósnia, federação de repúblicas, enquadrara três nações, a eslovena, a croata e a sérvia, o que evitou o confronto entre as duas últimas, do mesmo modo que a República da Macedónia contrariou o imperialismo dos Sérvios no sul; a criação em 1974 das províncias autónomas do Kosovo, de maioria albanesa, e da Voivodina, de maioria húngara, facilitou as relações de paz. Mas a diversidade e complexidade regional também potenciava, como veio a suceder, a afirmação e radicalização de nacionalismos com base em culturas imaginadas como 'autênticas' e diferentes da cultura do outro, a excluir, que criou minorias não integradas e alimentou estratégias de depuração étnica, cultural e religiosa. As tensões entre países vizinhos, a instabilidade das fronteiras linguísticas, culturais, religiosas e políticas ao longo da história, os seus traçados recentes, segregaram minorias mais ou menos oprimidas em quase todos os novos estados, mas sobretudo na Sérvia, Kosovo, Macedónia.

A ordem repressiva mas pacífica dos Estados que não acreditavam na existência de Deus foi substituída pela violência de povos dedicados a deuses diferentes, num processo que foi estimulado com a promoção de eleições por repúblicas da ex-Jugoslávia e não a nível do todo federativo: desse modo foram criadas condições para o não respeito do princípio de estados multiculturais e multiétnicos, e para o aparecimento de conflitos entre os restos confessionais do catolicismo 
romano, da ortodoxia oriental e do Islão e dos impérios de base, o austro-húngaro, o russo e o otomano, na leitura de Huntington (2001: 309). Assim, a fronteira da Croácia, segundo este autor, deve ser vista como a fronteira da Europa. Fronteira que foi apoiada, ainda em 1991, pela Alemanha, ao reconhecer a independência da Croácia, tal como fizera antes com a Eslovénia, sob a pressão da diáspora croata e da igreja católica bávara, e pressionando em seguida os restantes membros da UE a idêntico reconhecimento, desde logo os vizinhos, Áustria e Itália, além do Vaticano.

Pela sua história conturbada o sudeste da Europa apresenta-se muito dividido, no que foi agravado nos finais do passado século pela 'balcanização' política da Jugoslávia, com bases essencialmente religiosas: católicos, ortodoxos, muçulmanos. Na verdade, ao longo dos anos 90, os Balcãs ocidentais foram de novo uma zona de forte turbulência, mesmo às portas da UE, no seguimento da decomposição territorial da federação de repúblicas em 1991, com a separação sucessiva da Eslovénia, da Croácia, da Macedónia e depois da Bósnia. A Alemanha reconheceu, individualmente, logo nos finais de 1991, as independências da Eslovénia, na fronteira com a Áustria e a Hungria, de maior influência italiana e austríaca e maior desenvolvimento económico, e da Croácia, também fazendo fronteira com a Hungria, com cultura ocidental e raízes latinas e católicas e uma economia diversificada, onde a agricultura dispóe de boas condições de desenvolvimento nas planícies de nordeste e o turismo na costa dálmata. A Sérvia ortodoxa teve apoios tanto da Grécia como da Bulgária e da Rússia, enquanto a Turquia apoiou a Bósnia, os sérvios ortodoxos lutando contra os croatas católicos e com os muçulmanos bósnios e albaneses, estes com ritmos de crescimento demográfico muito mais fortes e desse modo tendo vindo a impor-se em termos numéricos e pelas próprias estruturas etárias, bem mais jovens.

Neste mesmo quadro peninsular mas não tendo jamais sido integrada na ex-Jugoslávia, está a Albânia, pequeno país, de 28 mil km², também comunista mas que abandonou a União Soviética logo em 1961, reorientando-se para a China até 1976, quando inicia o seu isolamento internacional, político e económico. Tem fronteiras com o Montenegro, Kosovo, Macedónia e Grécia, e uma larga percentagem de população muçulmana: 70\% dos 4 milhões de albaneses são muçulmanos e estão espalhados por todo o país, mas também existem minorias católicas e ortodoxas. Foi província romana, bizantina, búlgara e sérvia e domínio turco a partir do século XV e até 1912, muito embora a independência total apenas tenha sido conseguida em 1920, perturbada todavia nos anos $30 \mathrm{e}$ durante a II Grande Guerra, com a ocupação militar italiana. Conta com território montanhoso, clima claramente mediterrâneo, matizado pelo relevo, e escassas potencialidades agrícolas. Fez a sua reforma agrária, primeiro com repartição da terra pelos camponeses, na base de 5 hectares por família, e logo em seguida com eliminação da propriedade privada, desenvolvimento de cooperativas de produção, colectivização total das explorações, preferência por explorações estatais, modernização tecnológica e intensificação dos sistemas produtivos 
e esforços de aproximação entre os camponeses e os operários, entre os meios rurais e os urbanos. Nos meados dos anos 70 a Albânia definiu estratégias de total isolamento, mesmo em relação aos estados vizinhos, valorizando prioritariamente o auto-abastecimento alimentar (não esquecer a inspiração do modelo chinês, com a comuna popular) e industrial, estratégia que atenuou nos anos 80 .

Evoquemos a Albânia actual com as palavras de A. Vítor RibeIro («Pública», 20 de Novembro, adaptado), como se segue: o tempo vai-se entretanto escoando para este país que parece persistir em desdenhar da sua geografia privilegiada. Entre a prosperidade italiana e as nações balcânicas que se reerguem rapidamente e espreitam a integração europeia, com acesso privilegiado ao Mediterrâneo, a situação da Albânia constituirá um caso atípico, aberrante, na rudeza balcânica. Há 25 anos, a Albânia tinha alguma indústria, embora já algo obsoleta: metalúrgica, do crómio e um pouco de refinação de petróleo, financiadas pelos chineses. Nos anos 60 e 70, foi tentado um equilíbrio entre agricultura e indústria, com relativa prosperidade através da cooperação com a União Soviética, até 1962, depois com a Jugoslávia e mais tarde ainda com a China maoísta, todos dando auxílio, enviando dinheiro, técnicos e ajudando na criação de infra-estruturas. Ainda hoje circulam nas estradas albanesas velhos camiões de fabrico chinês dos anos 60.

Então os padrões de vida não eram tão miseráveis como se tornaram nos anos 80 , com o fechar ao mundo, o culto do isolamento, os cenários apocalípticos, testemunhados ainda hoje pelos velhos abrigos atómicos, dispersos pelo território, os parques urbanos decrépitos, o aspecto sinistro dos subúrbios escassamente iluminados das cidades, os blocos de apartamentos ao estilo soviético, velhos e degradados, todos iguais, as ruas esburacadas, o lixo por todo o lado e muita, mesmo muita negligência. Nos campos, a força de trabalho masculina escoa-se para Tirana, a capital, ou para Itália, Zurique ou Nova Iorque, numa hemorragia permanente e largamente clandestina de um país ainda marcado por um ruralismo persistente: numa sociedade profundamente patriarcal e medieval, asfixiante para as jovens, onde a honra ainda é vingada com sangue, as que ficam nas aldeias, sem noivo nem marido, acabam por abandonar o país com a promessa atraente mas aparente de casamento, seguida de engano, e por vender o corpo, o rosto e a idade.

Continuemos com A. Victor Ribeiro. Desde que a democracia se instalou na Albânia o país tem sido um santuário de todo o tipo de missionários, desde fundamentalistas sauditas a mórmones norte-americanos, de aspecto impecável e sorriso beatífico: o Islão balcânico é profundamente tolerante, já que tributário da herança otomana, onde não há lugar para partidos de cariz étnico ou religioso; o nacionalismo albanês é hoje o da diáspora. A anarquia que se instalou nos anos 90, a fraqueza do estado, permitiu a explosão da economia paralela, a multiplicação de actividades ilícitas, das redes mafiosas mais ou menos organizadas, do tráfico de seres humanos... Tudo se trafica na capital: na praça, muitos homens ociosos, cambistas, telemóveis de última geração, prosperidade e miséria, a Europa e a Ásia Central, mulheres e crianças. É muito forte o contraste entre a zona moderna e 
próspera e o norte da cidade, desolado, de prédios inacabados, barracas miseráveis por vários quilómetros, estações improvisadas de lavagem de automóveis e recauchutagens, carros velhos como escritórios, ausência de fábricas, nenhuma produção industrial, que entretanto desapareceu.

Neste quadro político fragmentado e complexo da península balcânica ganham prioridade o estabelecimento de relações normais com todos os estados vizinhos, a democratização e o estado de direito, assim como o desenvolvimento económico, numa palavra, a 'europeização' dos Balcãs, para os próprios e para outros estados que são de há muito membros da UE: a Itália, a Grécia e a Áustria, desde 2004 a Hungria, acompanhada pela própria Eslovénia, e a breve prazo, a Bulgária e a Roménia. A Itália, pela sua fachada adriática, exposta aos fluxos de emigração clandestina e de refugiados políticos da Albânia e do Kosovo, e pelas fronteiras terrestres com a Eslovénia; a Grécia, que alguns descrevem como um enclave comunitário, para atenuar os constrangimentos de descontinuidade e isolamento terrestre relativamente ao território da UE e pela instabilidade nos países situados a norte, da Albânia à Macedónia e à Bulgária, e não menos por pressões imigratórias sobre estas suas fronteiras terrestres e sobre as marítimas, que são fronteiras da UE.

A 'europeização' acima referida passa pelas perspectivas de inserção na dinâmica europeia, por certo um processo longo e exigente de muitos apoios: a integração numa união democrática, pluralista, respeitadora da diversidade cultural e religiosa, actuantes no respeito pela subsidiariedade - como precisado no tratado de Maastricht em 1992 - é a melhor oportunidade para a segurança, paz, solidariedade, compreensão e respeito mútuos, possibilidades de desenvolvimento nas vertentes económica e social. Falta identidade, mas a identidade (...) simula-se, constrói-se e reconstrói-se, e manifesta-se de formas irrisórias, lembra-nos Foucher (1998:112). Persistem, por outro lado, muitos problemas de minorias, e entre estas, as minorias ciganas, que evocámos a propósito da Roménia e da Bulgária. Povo com origem na Índia e que começou a dispersar-se há cerca de 600 anos, compreende várias comunidades distintas, com suas histórias, línguas, valores e hábitos, que se misturaram de forma independente e que incorporaram indivíduos não ciganos. Vivem hoje na Europa 8-10 milhões de pessoas da etnia cigana, predominantemente ainda não radicadas.

\section{ALARGAMENTO A OUTROS ESTADOS, A MÉDIO E LONGO PRAZO?}

Os adversários de novos alargamentos insistem na inevitável alteração profunda da natureza da UE, tendencialmente caminhando para apenas um grande mercado, o que agradaria por certo a muitos europeus do Reino Unido e da Suécia e, no caso do alargamento à Turquia, insistem com o mesmo vigor crítico nas consequências associadas ao facto de a UE passar a ter fronteiras com 
o Iraque, Irão, Síria e repúblicas do Cáucaso (Arménia, Azerbeijão e Geórgia). Inversamente, os defensores da integração da Turquia relevam a importância de a UE construir uma ponte entre o Ocidente e o Oriente e de poder contar com o exército turco em apoio da PESC. Loureiro dos Santos (Público, 29 de Outubro 2004, adaptado) justifica, como se segue: Existem áreas periféricas que é extremamente vantajoso incorporar na UE. Por um lado, acrescentam o seu poder global, o que é sensível no domínio económico (...). Por outro lado, porque ficam de fora ameaças que colocam em perigo a União tal como ela é se as suas fronteiras estratégicas não absorverem os restantes países balcânicos, do Leste europeu até à planície russo-ucraniana, a Turquia, o Médio Oriente e o Norte de África (...). Sempre no respeito pelos direitos humanos, democracia política e económica e acesso a direitos sociais compatíveis com a prosperidade económica atingida. Sempre sem inclusão de critérios meramente geográficos, históricos, étnicos ou religiosos.

José Cutileiro completa este ponto de vista do seguinte modo (Expresso, 18 de Dezembro 2004): A União Europeia tem problemas sérios no seu futuro, três dos quais a entrada da Turquia ajudaria a minorar muito, senão a resolver - falta de capacidade militar; falta de mão-de-obra; imagem exterior de cidadela cristã (...). Uma Turquia integrada na Europa seria barbacã perante ameaças vindas do Cáucaso ou do Médio-Oriente, enquanto que uma Turquia rejeitada pela Europa começaria a desocidentalizar-se e transformar-se-ia em testa-de-ponte dessas ameaças (...). A Turquia é um país de religião muçulmana e regime político laico e desde os anos 20 desenvolveu um notável processo de ocidentalização, incluindo a mudança do alfabeto (...). Sem a discussão bizantina, sem fim, sobre os limites e a essência da Europa.

Em oposição, outros analistas insistem em que há que previamente definir os limites geográficos da UE, a identidade europeia, e avaliar se a UE está preparada para fazer fronteira com países como o Iraque, o Irão e a Síria e para receber 80 milhões de muçulmanos turcos, mesmo se a adesão da Turquia nunca ocorrerá antes de 2015. E levantam a questão: A Europa vai implodir! Como lembrara Foucher (1998: 100-101), seria demagógico iludir a questão ou fazer crer que cada estado integrará a União como se esta fosse apenas uma organização multilateral suplementar e banal, não obstante a sua geografia variável e a realidade das cooperações reforçadas. É igualmente desestabilizador admitir que a Europa deve ser organizada segundo uma lógica de inclusão/exclusão com carácter definitivo, a inclusão política não sendo nunca um direito. A questão é na verdade muito complexa. Para Carlos Vale Ferraz, pode mesmo estar em causa favorecer o desencadear de conflitos que causem dificuldades aos principais competidores, como alguns estados membros da UE, nomeadamente dificuldades de abastecimento em petróleo e gás natural, e em particular de conflitos culturais e civilizacionais entre o mundo cristão e o mundo islâmico em torno das fronteiras da Europa e no seu seio, já que esta acolhe grandes comunidades muçulmanas e judaicas. Uma Europa cercada e internamente desestabilizada deixará de ter condições para prosseguir o seu modelo de desenvolvimento e verá diminuídos os seus factores de competitividade. 
E. LOURENÇo lembra, por sua vez: É, no geral, assumido que a UE não é um super estado europeu à imagem dos EUA, com fronteiras claramente definidas, não corresponde a um projecto apenas da península europeia da Eurásia, mas a um projecto de integração regional, baseado no multilateralismo e na inclusão, que evite guerras, respeite e proteja as singularidades culturais, as diversidades, as crenças religiosas e ideológicas. Os valores comuns são a democracia e os direitos fundamentais, os direitos cívicos, sociais e políticos, culturais e linguísticos, o laicismo e a liberdade religiosa, a liberdade de expressão e a não discriminação por sexo ou etnia. O cristianismo não deve em nada afectar o projecto europeu, não obstante a riqueza das suas matrizes, a «matriz greco-romana», a "matriz cristã ou judaico-cristã» (Público, 27 de Outubro 2004, adaptado).

Para Amin MAalouf importa sobretudo evitar o choque de civilizações, promover a coexistência ocidente-oriente, no respeito por valores universais como o conhecimento, a democracia, a liberdade («Pública», 21 de Novembro 2004, adaptado), pelas identidades, cada vez mais religiosas: uma sociedade secular não pode admitir qualquer mistura entre religião e política mas a religião tem sido uma afirmação de identidade e não apenas uma crença (...). O mundo árabe perdeu a sua identidade, o rumo, não tem perspectiva, não tem nada para propor ao mundo (...) e o Ocidente tem vindo a perder credibilidade, capacidade de transmitir os seus valores ao mundo. Mas previne também: o direito à diferença é um slogan do apartheid; dar direitos às comunidades é equivalente a tornar cidadãos prisioneiros das suas próprias comunidades, é submeter as pessoas às suas comunidades, hábitos, costumes, tradições, regras impostas, guetos (...). Um país não é uma federação de comunidades, o Estado não deve acomodar comunidades ou dar-lhes quotas, não deve encorajar subúrbios separados e culturas segregadas numa mesma cidade, só para manter diferentes estilos de vida, mesmo se sem comunidades possa parecer mais difícil os imigrantes conservarem a sua identidade e a sua cultura.

\section{A Europa de leste e as fronteiras orientais da União}

A Europa não tem fronteiras fixas. Só a União, processo político, é claramente delimitada, por decisões sucessivas. Para lá das suas fronteiras institucionais estendem-se domínios em vias de 'europeização', forma contemporânea de difusão de uma coexistência entre nações que sonha um alcance mais universal (Foucher, 1998: 127). Muitas fronteiras políticas dos Estados europeus datam dos meados do século XX e só recentemente têm sido fixadas nos seus detalhes, outras multiplicam-se nos finais do mesmo século, com o processo de desagregação dos territórios, multiplicando ao mesmo tempo as inseguranças e os conflitos potenciais e reafirmando o interesse dos programas de cooperação regional e local promovidos pela União especificamente para as suas regiões de fronteira, internas e externas. Com tais programas, desvaloriza-se o significado político, económico e social das fronteiras internas, e ao mesmo tempo atribuem-se papéis reforçados às fronteiras externas da UE, essencialmente pelo controlo 
de fluxos imigratórios mas também pelo de actividades ilícitas e do terrorismo, numa UE que se não pretende apenas económica mas também social e política, como foi oportunamente reforçado nos anos 90, nos tratados de Maastricht e de Amesterdão.

Na concepção de Huntington, no quadro dos impérios czarista e comunista formou-se um bloco civilizacional com um núcleo central, equivalente ao da França e Alemanha para o bloco ocidental. No círculo interior integravam-se as repúblicas predominantes, ortodoxas e eslavas, da Bielorrússia e da Moldávia, Kazaquistão, em que $40 \%$ da população é russa, e a Arménia, um íntimo aliado histórico da Rússia (...). As relações entre a Rússia e a Geórgia, predominantemente ortodoxa, e a Ucrânia, em grande parte ortodoxa, são mais ténues (...). Nos Balcãs ortodoxos, a Rússia tem relações próximas com a Bulgária, a Grécia, a Sérvia e Chipre e, em menor grau, com a Roménia (...). Globalmente, pode dizer-se que a Rússia está a criar um bloco com um núcleo central ortodoxo sob a sua liderança, rodeado por um 'amortecedor' formado por um conjunto de estados islâmicos, relativamente fracos, que, em vários graus, domina e donde tentará expulsar a influência de outras potências (...). Enquanto a União Soviética era uma superpotência com interesses globais, a Rússia é uma grande potência com interesses regionais e civilizacionais (...). Os países ortodoxos da ex-União Soviética têm um papel primordial no desenvolvimento de um bloco coerente na Eurásia e nos assuntos internacionais (2001: 191-192).

Os países da Europa de leste - Bielorrússia, Ucrânia, Moldávia e Rússia mantêm hoje relações externas preferenciais não apenas com a Rússia mas igualmente com a UE e beneficiam dos seus apoios. As suas fronteiras ocidentais são as da área de influência ainda dominante da Rússia e coincidem grosseiramente com as fronteiras anteriores à II Guerra Mundial. A Bielorrússia, com $207 \mathrm{mil} \mathrm{km}^{2}$ e um pouco mais de 10 milhões de habitantes, prolonga para sul os estados bálticos, para leste a Polónia e para noroeste a Ucrânia. A sua geografia apresenta muitos traços comuns com esses seus vizinhos: na topografia também plana, largamente pantanosa, não obstante os trabalhos de enxugo, e com abundantes turfeiras; no clima continental moderado, apreciavelmente chuvoso e húmido, pela influência oceânica de oeste e pela do próprio mar Báltico; na cobertura florestal, de folhosas, e na abundância de prados e extensões forrageiras. A população estagna, envelhece e concentra-se em centros urbanos. A economia manteve uma forte componente agrícola, com destaque para os cereais e a pecuária, mas dispõe também de um sector industrial variado, que registou forte desenvolvimento no decénio de 1970-80. Para tal desenvolvimento contribuíram as facilidades de transporte e comunicação, a disponibilidade de recursos, como material lenhoso, turfa, petróleo e sal, e as facilidades de abastecimento energético a partir dos oleodutos e gasodutos provenientes da União Soviética: além dos têxteis e confecções, indústria mecânica, incluindo fabrico de automóveis e tractores, material eléctrico, química e petroquímica, materiais de construção, com destaque para casas pré-fabricadas, derivados da madeira, celulose e papel, e ainda indústrias alimentares, a partir da carne e do leite. 
Huntington sublinha que a Bielorrússia tem pouca consciência da identidade nacional. Está também dependente do apoio russo. Muitos dos seus residentes parecem identificar-se mais com a Rússia do que com o seu próprio país (...). A Bielorrússia cedo aderiu à Comunidade de Estados Independentes (CEI); foi membro fundador da união económica criada em 1993 com a Rússia e a Ucrânia concordou com a existência de uma união monetária com a Rússia (...). Em 1995 a Bielorrússia era, de facto, parte da Rússia, excepto no nome (2001: 192).

A sul-sudeste ficam a Ucrânia e a Moldávia, também elas planas e de clima continental, de invernos atenuados à medida que nos aproximamos das margens do Mar Negro (Crimeia balnear e turística, à semelhança da Côte d'Azur, russa desde Catarina II e anexada à Ucrânia no quadro da URSS) e maior secura na parte mais oriental, domínio das estepes, por mais exposta aos ventos de leste que transportam pó e areias. Na cobertura vegetal, o destaque vai para extensões florestais de folha caduca e campos limpos, abertos e de malha muito larga, e a sul, algumas formações vegetais mediterrâneas, e cultivos do tabaco, vinha e pomares. Estes países contam grandes extensões de solos férteis (chernozion ou terras negras/loess na Ucrânia e na Moldávia), bons para o cultivo dos cereais em grande escala, moderno, com largo recurso à rega e integralmente mecanizado, que foi organizado em vastos kolkhozes, associando produção agrícola e criação animal, nos pastos e estabulada e intensiva. Valoriza-se nomeadamente a produção de trigo, em rotação com a beterraba sacarina e o girassol (ao lado dos cereais pobres, como cevada e centeio, batata e pecuária extensiva, nas áreas mais a norte e de clima mais rude), a Ucrânia e a Moldávia funcionando como celeiro dos países de leste, mesmo da Rússia, e outrora, no quadro do sistema latifundiário, do império turco e de muitos países europeus ocidentais, aonde o trigo chegava através de Odessa e do Mediterrâneo. Ocupam-nas populações numerosas - 50 milhões de habitantes na Ucrânia e um pouco mais de 4 milhões na Moldávia - e ainda muito rurais, se exceptuarmos a bacia hulheira de Donbass, que continua a ser explorada nos princípios do século XXI, e que alimentou, conjuntamente com o minério de ferro de Krivoy Rog, o desenvolvimento precoce da indústria pesada. No seguimento desta história industrial e dos recursos dispo-níveis - carvão, minério de ferro, energia térmica, hidroeléctrica e nuclear, como na malograda central de Chernobil, e gás natural foram desenvolvidas na Ucrânia, no quadro do COMECON, actividades industriais variadas: siderurgia, metalurgia, construções mecânicas, com destaque para a maquinaria agrícola, química, celulose e papel, têxtil, indústrias alimentares.

A Ucrânia é 'terra de fronteira', como o sugere o próprio nome, e dos cossacos submetidos aos czares da Moscóvia, que a russificaram (apoio dado aos cossacos pelos czares, contra os polacos, na segunda metade do século XVII), nomeadamente desde 1876, com a proibição de publicações em língua ucraniana. É um país geograficamente europeu e de tradição cristã, com uma área superior à da França, uma população maior que a da Espanha, da ordem dos 48 milhões de pessoas, eslava como a da Bielorrússia, uma acentuada diversidade étnica, uma identidade nacional cívica e não étnica ou linguística e Kiev 
como capital. É a ex-república soviética mais populosa e mais importante, se exceptuarmos a Rússia, mas é também um país dividido, com duas culturas distintas. A fronteira civilizacional entre o Ocidente e a ortodoxia passa, desde há séculos, em pleno coração da Ucrânia. No passado, durante alguns períodos, a Ucrânia Ocidental pertenceu à Polónia, à Lituânia e ao Império Austro-Húngaro. Uma grande parte da sua população tem estado ligada à Igreja uniata, que pratica os ritos ortodoxos, mas reconhece a autoridade do Papa (...). Os habitantes da Ucrânia Oriental (...) são esmagadoramente ortodoxos (Huntington, 2001: 193). Ocupa uma posição privilegiada ao longo dos eixos de travessia da Europa nas direcções norte-sul e oeste-este, é a grande fronteira entre a NATO e a Rússia, uma peça de elevado valor no tabuleiro geopolítico. Independente há uma quinzena de anos (finais de 1991), integrara a URSS e integra a CEI.

Terá a Ucrânia, de facto, uma vocação europeia, como pretendido por uma parte significativa da sua população e não menos pelas vizinhas Polónia e Lituânia? A parte ocidental do país foi terra polaca e do império austro-húngaro, o centro e leste, de economia mais industrial e desenvolvida, pertenceram ao Império russo desde o século XVI. Kiev, a capital desde 1934, fica a oeste: sucedeu a Kharkov, situada no sudeste. As indústrias mineira, metalúrgica, militar e espacial, básicas para a riqueza do país na medida em que asseguram claramente mais de $2 / 3$ do PIB, estão porém localizadas na parte oriental e de sul. As últimas eleições presidenciais mostraram um país dividido entre o oeste que fala ucraniano e o leste falando russo, vistos pela imprensa, respectivamente, como mais democrático e mais autocrático, mais orientado para o Ocidente ou para a Rússia. A Ucrânia vivia então uma situação económica crítica, com uma moeda muito desvalorizada, uma sociedade ainda acentuadamente rural, e indústrias tecnicamente obsoletas, não competitivas e sem mercado, áreas industrializadas decadentes, com graves problemas ambientais e de desemprego; e uma situação política instável e minada pela corrupção. Com a crise económica e o desemprego muitos ucranianos emigraram para o Ocidente, incluindo Portugal, onde existe uma grande comunidade espalhada por todo o país: cerca de 65 mil imigrantes legalizados; com os ilegais, serão perto de 120 mil.

A plena separação da Ucrânia da Rússia não parece ser facilmente aceite por esta, pois sem a Ucrânia a Rússia deixa de ser um império na Eurásia, perde a possibilidade de reorganizar um espaço económico comum envolvendo a Bielorússia e estendendo-se pelo Cáucaso e Ásia central, com toda a riqueza dos seus recursos energéticos. Aqui, porém, tem vindo a perder influência e mesmo o controlo das rotas do petróleo do Mar Cáspio, depois do seu afastamento do Afeganistão e da Ásia Central, a favor dos EUA, assim como no Cáucaso, na Geórgia, com regime militantemente pró-ocidental. Inversamente, aos EUA interessa a extensão oriental da órbita euro-atlântica, incluindo a Ucrânia independente, desse modo impedindo o reafirmar de um império russo, razão por que se tornaram o maior financiador de Kiev. A Ucrânia está pois dividida entre a influência russa e a ocidental: uma parte da elite dirigente aspira a entrar na NATO e um dia não muito distante a entrar na UE, outra permanece ligada a 
Moscovo por laços muito fortes, dependência energética e económica. Haverá o risco de a Ucrânia vir a ser efectivamente desagregada e dividida pelo jogo das influências do Ocidente e de Moscovo, repetindo-se nas eleições pós-independência a oposição entre os eslavos europeizados, na parte ocidental, e a população russo-eslava? Contudo, as relações russo-ucranianas são para a Europa de Leste o que as relações franco-alemãs são para a Europa ocidental. Tal como estas fornecem o núcleo duro da União Europeia, aquelas constituem o equivalente para a unidade do mundo ortodoxo (HunTINGTon, 2001: 196).

Na opinião de João Cravinho (Diário de Notícias, 17 de Maio 2003): Resta ainda o problema da Ucrânia, que quer aderir, para não falar da Moldávia e da Bielorrússia. Não é de somenos para toda a Europa a estabilização e democratização da Ucrânia, a Pequena Rússia, berço histórico da Grande Rússia, significativa potência nuclear, vizinho receoso da Rússia que tem na Crimeia, na Ucrânia, a poderosa Frota do Mar Negro. Mas não haverá outra solução senão a adesão? Como poderá a Rússia integrar uma casa europeia comum, como pareciam esperar Mickhail Gorbatchev e François MiterRand? Que passos serão dados no seu processo de ocidentalização, para além do Conselho da Europa, da OSCE, da participação nos trabalhos do G7/G8, etc.? Não esqueçamos que São Petersburgo e mesmo Moscovo como sociedade urbana, estão mais próximas da Europa que das zonas rurais ou arqueo-industriais da Bielorrussia ou da Ucrânia, talvez mesmo que Minsk ou Kiev (LÉvy, 1997: 193).

A fronteira entre a Rússia e a NATO vai das margens do Mar Báltico às do Mar Negro, mas a Rússia faz parte de um Conselho da NATO, ao contrário da Ucrânia, que não a integra. A Rússia é tão europeia como asiática, a federação russa ocupando toda a parte asiática, mas não as três nações ocidentais, consideradas atrás, e as três do Cáucaso. É europeia pela sua cultura, religião - cristãos ortodoxos - e história económica. A Rússia participa da Europa económica e nomeadamente da Europa da energia, como os países do Cáspio, e a Europa é muito dependente do petróleo e gás da Rússia, Kazaquistão, dos países do Cáspio e do Médio Oriente, sendo-lhe particularmente importante assegurar o abastecimento por oleodutos, através do território russo, e não menos o acesso às suas principais estradas, que funcionam como corredores de transporte e de ligação da Europa ocidental com a Ásia e o Cáucaso. De notar que os americanos tentam desalojar a Rússia do Cáucaso, apoiando especificamente a Geórgia, constroem oleodutos alternativos para que o petróleo do Cáucaso não chegue ao Mar Negro e ao Mediterrâneo através do território russo e implantaram bases militares na Ásia central, em territórios que gravitaram na órbita de Moscovo.

A Rússia é um país pobre, com graves problemas de desenvolvimento, que sofreu a reorganização dos fluxos comerciais e a perda de mercados na Europa central e oriental, assim como as novas dificuldades de circulação da sua população, uma vez desmembrada a União das Repúblicas. Mas é um país com recursos abundantes, grande capacidade militar e 150 milhões de habitantes, que pode alargar o mercado da Europa a 700 milhões de pessoas: aliás, metade do comércio externo da Rússia é hoje feito com países da UE e a UE constitui 
a mais importante fonte de IDE na Rússia, apesar de algumas dificuldades de natureza burocrática e fiscal.

Para a UE a Rússia é também uma grande potência, com papel decisivo na garantia da paz e da estabilidade internacionais, que partilha fronteiras com regiões instáveis, e que pode desempenhar um papel de relevo no controlo dos fluxos da droga, armas, seres humanos ilegalmente traficados para a UE. Para a Rússia a UE representa um mercado de 450 milhões habitantes, com elevado produto interno bruto e peso político. A cooperação contra o terrorismo não é menos importante, quer pela troca de informação, quer no combate das suas causas, designadamente desemprego, ausência de políticas sociais, baixo nível educacional das novas gerações. Mas cooperação não significa integração na UE, que é não apenas união económica mas também união social e política.

Na opinião de LÉVY (1997: 189), por razões geopolíticas, que não cessaram de fazer sentir os seus efeitos, a Rússia não pode ser considerada, em nenhuma das suas regiões, como parte integrante da Europa. Constituiu durante muito tempo um território-fronteira pouco a pouco transformado num império inexpugnável, a sua 'desimperialização' parcial faz dela, por um tempo indeterminado, uma periferia a promover mas não a integrar. A Rússia não tem passado democrático, antes persistência ao longo da história de estruturas sociais tradicionais, senhoriais e dualistas, dominadas na base por comunidades camponesas e famílias alargadas dependentes dos grandes senhores da terra, que reapareceram na reorganização comunista da agricultura (kolkhoz e sovkhoz).

As tentativas de modernização, afirmação como potência do Báltico e ocidentalização, como a de Pedro o Grande, no século XVII, não impediram o aparecimento de formas de servidão ainda no século XVI e a sua manutenção até meados do século XIX; esta estreita ligação à terra e aos seus senhores explica a intensidade das reformas agrárias que se seguiram; as instituições, as crenças e os modos de vida asiáticos e bizantinos predominavam na sociedade russa e eram aceites por europeus e russos (...). A Rússia de Kiev e de Moscovo vivia separada do Ocidente e tinha poucos contactos com as sociedades europeias ocidentais. A civilização russa desenvolvia-se como um derivado da civilização bizantina e, durante duzentos anos, de meados do século XIII a meados do século XV, a Rússia foi dominada pela suserania mongol. Quase não foi exposta aos fenómenos históricos da civilização ocidental: o catolicismo romano, o feudalismo, o Renascimento, a Reforma, a Expansão ultramarina e a colonização, o século das luzes e o aparecimento do Estado-nação (...). A civilização russa foi um produto das próprias raízes - Rússia de Kiev e de Moscovo -, da importante influência bizantina e do prolongado domínio mongol (HUNTINGTON, 2001: 163-164).

A revolução socialista e a sua afirmação como grande potência económica, político-ideológica e militar do século XX, não apagaram as suas especificidades históricas, uma larga zona de passagem da Europa para a Ásia, uma civilização ortodoxa e euro-asiática diferente. Huntington (2001: 166) lembra que, após o colapso do comunismo, o debate sobre a identidade da Rússia se centrava na questão: Deveria a Rússia adoptar os valores, as instituições e as práticas ociden- 
tais e tornar-se parte do Ocidente? ou deveria corporizar uma civilização ortodoxa e euro-asiática diferente da do Ocidente cujo destino seria ligar a Europa e a Ásia, que opunha ocidentalistas e nacionalistas, estes divididos entre os claramente centrados nos russos, ou seja, na Rússia, Bielorrússia, Ucrânia e eslavos ortodoxos e outros mais imperialistas, e mais orientados para as ligações com os turcos e o sul muçulmano, a Ásia e o Oriente.

As mudanças dos últimos vinte anos traduziram-se na desintegração do grande mercado soviético e das suas relações de cooperação e de complementaridade, no desmantelamento dos monopólios estatais e privatização do sistema produtivo, abertura ao exterior, inserção na economia global, em clara oposição ao isolamento concorrencial, no quadro da União das Repúblicas, e ao estatismo de quase todo o século XX. A liberalização do mercado criou dificuldades em sectores e empresas pouco ou não competitivas, com reflexos no emprego, dos quadros técnicos e administrativos e dos seus trabalhadores menos qualificados, instabilidade social, desqualificação dos serviços públicos, degradação das condições de vida, acentuação das suas assimetrias, economia subterrânea, afirmação de máfias, corrupção e insegurança, emigração para o Ocidente.

Uma Rússia moderna e próspera convém à UE, por mais comércio, investimento, inovação e menos poluição ambiental e imigração clandestina. Daí é o reconhecimento pela UE da Rússia como nação mais favorecida, o que lhe assegura facilidades de exportação, e também o apoio para a integração da Rússia na OMC. Ao mesmo tempo, intensificam-se as cimeiras UE-Rússia, como a de Haia, em Novembro de 2004, com vista ao reforço da cooperação para criação de espaços comuns a médio-longo prazo e dentro do Acordo de Parceria e Cooperação, na base de valores comuns e interesses partilhados. Os espaços comuns cobrem as áreas económicas e ambientais, liberdade, segurança e justiça, segurança externa, gestão e não proliferação das crises, investigação e educação, incluindo aspectos culturais, e negociação de um pacote do futuro mapa de estradas da Europa e mesmo da Eurásia, como se segue:

- Espaço económico comum: aumentar e diversificar as trocas comerciais e criar novas oportunidades de investimento com vista à integração e regular a convergência, abertura de mercado, facilidades comerciais e desenvolvimento das infra-estruturas; o espaço económico comum cobre objectivos de comércio, investimento, cooperação industrial, políticas de empresas, e áreas mais específicas, como direitos de propriedade industrial, competição e agricultura, energia, transportes, como os projectos de infra-estrutura, segurança marítima, satélites de apoio à navegação e à aviação, cooperação em questões ambientais.

- Espaço de liberdade, segurança e justiça: direitos humanos, direitos das minorias, liberdades fundamentais, liberdade de comunicação e informação; no campo da justiça e assuntos internos, questões referentes ao crime organizado, terrorismo e actividades ilegais que cruzam as fronteiras, de modo a ser conseguido o equilíbrio entre segurança por um lado e justiça e liberdade, por outro, 
o combate ao terrorismo sempre feito no pleno respeito dos direitos humanos; objectos de análise comum são também as condições dos vistos entre UE e Rússia, numa perspectiva de longo prazo, as migrações e o controle de fronteiras, incluindo a fronteira entre a Rússia e a Lituânia, e também a fixação pormenorizada das fronteiras com a Estónia e a Letónia.

- Espaço de segurança externa: pela gestão de crises, combate ao terrorismo, proliferação de armas de destruição maciça, conflitos regionais e cooperação em termos de protecção civil em caso de acidentes naturais e outras situações de emergência, com prioridade geográfica para o espaço da UE de maior vizinhança com a Rússia, através da Bielo-Rússia, Moldávia e Ucrânia. Como grande objectivo, encontrar com a Rússia soluções comuns para ultrapassar conflitos e promover estabilidade e prosperidade, e uma ordem internacional baseada no multilateralismo, reconhecendo a importância das Nações Unidas, da OSCE e do Conselho da Europa.

- Finalmente, o espaço de investigação, educação e cultura: com vista ao aumento da competitividade das economias da UE e da Rússia, que passa pelo mobilizar da herança intelectual e do capital de conhecimento através de acordos de cooperação científica e técnica, que vêm de 2002 e 2003, e de planos de acção para promover a cooperação em matéria de investigação e desenvolvimento.

A Turquia é um país asiático, com um pequeno enclave europeu, a que apenas correspondem $5 \%$ do seu território e $8 \%$ da sua população, faz fronteira com a Grécia e a Bulgária mas sobretudo com países do Médio-Oriente, que outrora integraram o Império Otomano, assim como com o Irão e a Arménia. Tem uma posição de encruzilhada entre os Balcãs, o Cáucaso e o Médio Oriente e de ponte entre a Europa democrática e fortemente cristã e os estados árabes e islamistas, que pode fundamentar estratégias opostas: democracia, laicidade e integração na Europa, na continuação do caminho secular e pró-ocidental, democrático e com economia de mercado, iniciado por Mustafa Kemal Ataturk, nos anos 20 e 30 do passado século, para a república turca, ou viragem para o Cáucaso e a Ásia central, onde vivem povos turcófonos (Azerbeijão e saída do petróleo do Cáspio para o Mediterrâneo, por oleoduto através da Turquia; ex-repúblicas soviéticas do Uzbequistão, Turquemenistão, Kazaquistão e Quirguistão), contrariando designadamente o alargamento da influência do Irão e da Arábia Saudita, sem secundarizar o desenvolvimento de relações preferenciais com o mundo islâmico, incluindo os muçulmanos da Bósnia e da Albânia, em oposição clara a uma possível aliança ortodoxa greco-servo-búlgara. O ressurgir dos valores islamistas e o regresso à religião foi mais acentuado nos anos $80 \mathrm{e}$ princípios de 90 do passado século.

Encruzilhada geográfica, histórica e também étnica e política, com um confuso legado de identidade nacional, pelo que a negação das negociações de 
adesão à UE geraria uma grave crise de identidade e agitação e instabilidade às portas da Europa. 70 milhões de crentes culturalmente islâmicos, não uma gota de água mas uma presença avassaladora, que levanta o problema da livre circulação de pessoas, na certeza de que o Islão não se dissolve, resiste e prolifera no ocidente europeu! País pobre, com uma economia eminentemente rural, com pleno direito de acesso às ajudas regionais e agrícolas! (e por conseguinte, com consequências financeiras pesadas no Quadro Financeiro da UE). Sociedade muito mais oriental que europeia, mas que partilha da experiência e da cultura europeia, se recordarmos a história (E. Lourenço, Público, 27 de Outubro 2004, adaptado).

Para a Europa a Turquia poderá tornar-se no seu melhor aliado perante a real ou fantasma ameaça do Islão fundamentalista, capaz de o conter nos limites do aceitável. Continuando, Eduardo Lourenço, sempre muito crítico quanto a uma possível integração da Turquia na UE, acrescenta: seria fácil responder à questão que a candidatura da Turquia põe à Europa, se soubéssemos o que é a Europa e o que quer. Mas não é visivelmente o caso (...). Europa, soma de contradições e um objecto mais utópico que real, um espaço de diálogo e convívio, de querer, de pensar e de agir, que não tem sido o paradigma turco. Pode a Turquia vir a ser europeia? Para os turcos a Europa é o paradigma da modernidade, do progresso, embora a identidade turca seja definida pelo Islão e a Europa não tenha uma identidade do mesmo género, nem mesmo identidade.

A república turca data de 1923, no colapso do Império Otomano, em 1952 integrou a NATO, com a função de impedir a expansão da União Soviética para o Mediterrâneo, Médio Oriente e golfo Pérsico, e mais tarde, a de apoio dos EUA contra o Iraque de SADDAM HusseIn e outras ameaças islâmicas regionais; em 1963 assinou o primeiro Acordo de Associação com a CEE, depois tornou-se membro de pleno direito da União Aduaneira, e em 1999 apresentou-se de novo, e uma vez mais, como candidato à integração na UE como estado membro: o nível de convergência económica com a UE é superior ao de outros países então também candidatos, a integração facilitaria uma solução definitiva dos problemas de soberania territorial com a Grécia e a eterna questão de Chipre, e merece toda a atenção e estímulo dos EUA.

Em 2002, o Conselho Europeu de Copenhaga decidiu o início das negociações para finais de 2004 se o relatório da Comissão fosse positivo e nos finais de 2004 foi acordada a data para início das negociações, Outubro de 2005. A população turca, dentro de 20 anos, aproximar-se-á dos 90 milhões: constitui desde já um mercado significativo, que em 2003 foi avaliado em 2,8\% das exportações da UE e 2,4\% das suas importações; o rendimento per capita está estimado em apenas 1/5 do valor médio da UE 15 e em metade do correspondente aos 10 novos Estados-membros; a estrutura económica permanece ainda muito ligada ao sector primário, a agricultura representando mais de $10 \%$ do PIB.

Mas a Turquia apresenta também uma economia dinâmica, forte atracção de capital estrangeiro, uma elite milionária. Constitui além disso uma importante base de difusão para outros mercados vizinhos. Membro da NATO ainda durante a guerra-fria, com a sua adesão a UE passaria a contar com o impor- 
tante exército turco, numeroso e bem equipado, facto significativo para a política externa e de segurança comum. A união aproximaria também a Turquia da Grécia, o vizinho inimigo. Nos últimos anos, fez importantes progressos no campo dos direitos humanos, nomeadamente quanto à eliminação da pena de morte $\mathrm{e}$ ao respeito pela minoria nacional curda, localizada sobretudo no leste do país, da ordem de 20 milhões, pelo reconhecimento de direitos linguísticos, culturais, políticos, sociais e económicos.

A questão central é saber se a UE está realmente preparada para acolher um grande país muçulmano, pelo menos em termos demográficos, e para fazer face aos vultosos encargos financeiros que a adesão turca trará, para além da verificação de cumprimento pela Turquia, dos requisitos de adesão, fixados em Copenhaga. Relevam-se a abolição definitiva da pena de morte, a expansão dos direitos das minorias étnicas, o reforço dos direitos e garantias dos cidadãos, a extinção das restrições à liberdade de expressão e o reforço do controlo civil das instituições do Estado. Acresce ainda a questão de Chipre, a Turquia não reconhecendo a República de Chipre, membro da UE, com direito de veto. A situação remonta a 1974, no seguimento da guerra inter-étnica e da intervenção do exército turco, e não foi ainda ultrapassada pela oposição dos cipriotas gregos à reunificação da ilha recentemente proposta pela ONU. Terão igualmente de ser resolvidos os problemas territoriais com a Grécia no Mar Egeu...

Aceite ou rejeitada, a candidatura da Turquia questiona a Europa (...). A Turquia fantasma da Europa, o turco, objecto de pânico mas também de fascínio. A Europa do sudeste resistiu como pode à islamização e foi-se habituando à presença do poder turco em parte do seu território, estabelecendo relações comerciais e culturais de muito proveito, como o prova a história de Veneza, da outra Itália ou de França. De anti-Europa a Turquia passou a não Europa, serviu de testa-de-ponte na luta contra a União Soviética (...). Como recusar a Turquia, que a título histórico e, mais profundamente cultural, é não-Europa, se a Europa não tem uma definição ou ao menos uma perspectiva europeia de si mesma? (E. Lourenço, Público, 27 de Outubro 2004, adaptado).

Para os defensores da integração acrescem razões de natureza política e estratégica. Desde logo, demonstrar ao mundo islâmico as vantagens de trilhar o caminho da moderação e da democracia para modernizar e desenvolver os respectivos países. Por outro lado, a integração da Turquia teria um efeito estabilizador e internamente ajudaria as sociedades europeias a lidar com a realidade de a Europa ser ela própria cada vez mais islâmica. Sem esquecer que a Turquia, um país na encruzilhada de dois mundos, tem na Europa a cidade de Istambul, uma das grandes metrópoles do continente (13 milhões) cuja área de influência se estende por todo o sudeste, até à Ucrânia e à Ásia central. A integração da Turquia também aumenta a capacidade da UE para se projectar no mundo extra europeu e favorece o seu abastecimento energético: a posição geográfica da Turquia é única, não obstante o distanciamento geográfico e linguístico e a natureza de periferia de uma Europa a 25 ou a 29, e através da Turquia a Europa estende-se pela Ásia fora até ao Cáucaso. 
Martins da CRUZ, ex-ministro dos Negócios Estrangeiros de Portugal, releva o interesse político, estratégico e económico da abertura das negociações com vista à adesão. Na sua óptica, a adesão turca fará da UE um actor privilegiado no diálogo com o mundo islâmico, reforçará o poder europeu na NATO, abrirá o mercado europeu a mais de 80 milhões de pessoas e dará um sinal positivo ao islamismo moderado. A Turquia é um estado secular, com separação clara entre a religião e o Estado. Uma ponte para o mundo muçulmano, com os mesmos padrões democráticos da UE, islamismo moderado, uma mais valia para a Europa, na defesa, nas questões mundiais, nomeadamente no Cáucaso e no Médio Oriente, a melhor mensagem a enviar ao mundo muçulmano.

À adesão da Turquia opõem-se todavia claramente europeístas de renome, como o comissário austríaco Franz Fischler ou o presidente da Convenção que elaborou a proposta de Constituição Europeia, Valery Giscard D’Estaing. Para este último, integrar a Turquia seria acabar com a UE. A futura Constituição Europeia, ao estabelecer o princípio da dupla maioria, de países e de população para a tomada de decisões, impede a entrada da Turquia, pelo enorme peso que teria nas decisões, superior ao da Alemanha, embora sozinha nunca possa bloquear qualquer decisão europeia tomada por maioria qualificada e seja sempre possível os estados membros recorrerem a "cooperações reforçadas».

Mas Giscard D'Estaing também sublinha que o alargamento progressivo conduziu a um mal-estar crescente. Os europeus precisam de fortalecer a sua identidade (...). A Convenção Europeia procurou dar uma definição mais clara sobre as origens dessa identidade: a contribuição cultural da antiga Grécia e Roma, a herança religiosa difundida na Europa, o entusiasmo criativo da Renascença, a filosofia do período do Iluminismo e o contributo do pensamento racional e científico (...). A Turquia teve a sua própria história e a sua própria cultura (...). Não pôr em risco a frágil construção da $U E$, que ainda não se ajustou às consequências institucionais e orçamentais do último alargamento (...). Ultimamente, temos andado muito preocupados com a Turquia. Não será altura de darmos mais atenção à Europa? (Público, 27 de Novembro 2004). Por sua vez, João CRAVInHo faz notar que a adesão da Turquia não se pode justificar por razões de fidelização geopolítica, e que mais do que a adesão deve ser trabalhada a cooperação reforçada, económica mas também política, não sendo de todo natural levar as fronteiras da União Europeia ao Curdistão (Diário de Notícias, 17 de Maio, 2003).

Acompanhemos, a finalizar, as reflexões de TERESA De Sousa (Público, $14 \mathrm{de}$ Setembro 2004, adaptado), que considera a decisão sobre a adesão da Turquia, das mais difíceis e complexas para a UE e das com mais consequências a longo prazo. O problema de fundo será: pode um país islâmico integrar uma UE fundamentalmente cristã, pode um país oriental integrar uma união ocidental? O que determina, afinal, as fronteiras da Europa: a geografia e a História, ou a cultura e a religião? Há riscos de islamização da Europa? Não é o projecto europeu um projecto apenas político, não cultural, étnico nem religioso, uma resposta à necessidade de superar as diferenças culturais, religiosas, étnicas e nacionais da Europa através de uma união em torno dos mesmos valores políticos de democracia, dos direitos sagrados da pessoa humana e do Estado de direito? 


\section{Alargamento para outras margens do Mediterrâneo?}

Comecemos por acreditar em Edgar Morin: O Mediterrâneo não existe a não ser nas nossas subjectividades. O mito assenta em quatro princípios, segundo LÉvy (1997: 185): natureza, romanicidade, turismo, civilização. São grandes as disparidades de riqueza e desenvolvimento que hoje separam as suas margens, e fraca a sua unidade, uma zona de contacto cultural, uma fronteira de trocas mas também de justaposição hostil ou simplesmente de ignorância recíproca: O espaço mediterrâneo, como mensagem integradora da Europa a uma não-Europa ao mesmo tempo vizinha e distante, permanece uma utopia, e é talvez por isso que tem valor (idem, p. 189).

A Europa geo-económica abrange a Europa central, a Europa oriental e a Rússia, a Europa de sul e de sudeste, com os países balcânicos por um lado, e a Turquia por outro. Mas abrange de igual modo a Suíça, no coração da Europa, os países e territórios do Atlântico Norte - Noruega, Islândia e Gronelândia -, num caso e noutro altamente desenvolvidos, e quase todos os países envolventes do Mediterrâneo, sobretudo do Mediterrâneo ocidental e central, ou seja, os países do Magrebe - Marrocos, Argélia e Tunísia - e cada vez mais também a Líbia. A imagem alargada do espaço europeu é válida igualmente do ponto de vista migratório, de há muito estendido às margens meridionais e orientais do Mediterrâneo. É certo que o espaço migratório europeu se tem vindo a fechar, à medida que falta trabalho e se agravam os problemas de integração nos países tradicionais de acolhimento, num processo muito anterior à história recente, pós 1989-90, quando teve lugar a queda da barreira às migrações de leste assegurada pela cortina de ferro: então o espaço migratório europeu tendeu a ganhar as dimensões e os contornos do próprio continente. Na UE residem 4-5 milhões de estrangeiros vindos dos Balcãs, muitos deles romenos e búlgaros, a par dos albaneses e dos oriundos dos estados da ex-Jugoslávia e da Turquia, de moldavos, ucranianos, bielorussos e russos e de cerca de um milhão de emigrantes asiáticos. Mas residem também 3-4 milhões de emigrantes do Magrebe e da África.

Que tipo de relações são de esperar entre a nova UE e os países da margem sul do Mediterrâneo ocidental? A bacia mediterrânea tem uma longa história comum que remonta à Antiguidade e da qual herdou antigos focos de civilização, centros do mundo conhecido de outras épocas, um espaço marcado por intensos encontros e desencontros de pessoas e culturas, e não menos de trocas económicas. A margem sul do Mediterrâneo foi área de colonização tardia dos países da margem norte, que desenvolveram relações intensas e complementaridades múltiplas, tidas em conta na redacção dos objectivos gerais do próprio Tratado de Roma. No sudoeste, o Magrebe, ilha árabe-berbere ocidental, entre o Mediterrâneo e o Sahara, tem um nível de vida médio cinco a dez vezes inferior ao dos Estados mais próximos da Península Ibérica e da Itália. A UE é ao mesmo tempo o primeiro cliente e o primeiro fornecedor de bens e de fundos (Foucher, 1998: 86). Em 1984, FrançoIs DuchÊNE podia escrever: A Antiguidade transparece (...): a bacia do Mediterrâneo é uma das raras regióes do globo onde o capi- 
talismo, o socialismo e o Terceiro Mundo se encontram e talvez onde estão mais próximos. A comunidade europeia capitalista ocupa o noroeste da bacia mediterrânea, os Balcãs são socialistas, com excepção da Grécia e da Turquia; as margens oriental e meridional pertencem ao Terceiro Mundo, com excepção de Israel (1985: 9).

Sobrepovoadas, não tanto pelos volumes demográficos mas antes pela sua concentração nas regiões litorais, as margens não europeias do Mediterrâneo apresentam grandes densidades e populações adultas e jovens numerosas, ávidas de encontrar oportunidades de trabalho e melhores condições de vida e dominando a língua das velhas metrópoles coloniais. Assim, alimentaram fluxos migratórios intensos para a margem norte, legais ou mesmo clandestinos, através do sul de Espanha e do sul de Itália, enquanto alguns outros partiam em busca de formação científica e técnica e de novas experiências culturais e políticas. Importantes são também as relações de natureza económica, mesmo de puro negócio, favorecidas pelas estruturas empresariais, administrativas e de serviços herdadas do passado colonial, pela proximidade e pelas facilidades de comunicação através do domínio da língua dos colonizadores europeus. Outras relações, ainda com a direcção dominante norte-sul, assentam em motivações de lazer e turismo, e são facilitadas por laços familiares, hábitos de convívio, familiaridade com os espaços, apreço pelas culturas e patrimónios.

Nos anos 90, a UE disponibilizou uma ajuda financeira não menos volumosa que a destinada aos PECO, com objectivos de favorecer o desenvolvimento regional, estimular mercados para as suas exportações de valor acrescentado e contrariar desse modo os volumosos fluxos migratórios para a margem norte, numa população jovem com forte natalidade e crescimento e sem ocupação local. Os acordos tiveram lugar aquando da Conferência de Barcelona de 1995, que lançou o Diálogo Euromediterrâneo: em causa a criação de um quadro político e económico para as relações com os países da África do Norte e do Médio Oriente, que abrangeu três vectores: segurança e defesa, cooperação económica e democratização. Ao mesmo tempo, houve muito investimento privado, francês, espanhol e italiano, sobretudo em Marrocos e na Tunísia, e bem menos na Argélia, apesar dos seus recursos energéticos, por maior instabilidade política.

Os países do Magrebe fazem de há muito parte dos espaços geo-económico e migratório da UE, mas mantêm vivas as recordações das dependências coloniais, prezam as independências nacionais e as suas diferenças civilizacionais, assumem a continuidade da separação política ainda relativamente recente em termos históricos, a qual aliás perde significado num mundo cada vez mais global.

\section{REMATE}

A UE procura desenvolver a sua 'Política de Vizinhança', de modo a garantir a estabilidade à sua volta, melhorar a segurança fronteiriça, reduzir os fluxos migratórios, resolver alguns conflitos regionais, para tal reforçando as relações com os novos vizinhos, em particular com a Ucrânia, a Bielorrússia e 
a Moldávia, por onde é grande o 'Desejo de Europa', e também com os da orla mediterrânea, como Marrocos, Tunísia e os países do Próximo e Médio Oriente.

Desde logo, todos os membros da UE estão interessados em ter estabilidade e democracias nas suas fronteiras, do leste europeu, e portanto da Ucrânia, ao norte de África, o que significa cooperação, modernização e desenvolvimento dos vizinhos, não indiferente ao controlo das rotas de petróleo e gás.

É uma estratégia que os EUA procuram também desenvolver, com a vertente económica do Fórum do Futuro, que teve lugar nos finais de 2004, em Rabat: investimentos, alfabetização, formação de jovens empresários, criação de pequenas empresas com apoio de micro crédito.

$\mathrm{Na}$ estratégia da UE são admitidos, além dos programas de desenvolvimento, o acesso ao mercado interno europeu, a prazo e condicionalmente - liberdade de circulação de mercadorias, serviços e capitais, e também de pessoas em troca de reformas políticas, económicas e ambientais, e com respeito pelos direitos das minorias, como a minoria russa na Ucrânia.

Álvaro Vasconcelos (Expresso, 4 de Dezembro 2004) sintetiza assim: A crise na Ucrânia vem confirmar o lugar central que a União Europeia desempenha na segurança do próprio continente, usando como instrumento a inclusão democrática, ou seja, a paz através da integração económica e política, do respeito dos valores fundamentais e do princípio da associação entre os Estados, assente na diversidade (...). O dilema é o de saber se o que propõe com a chamada política de vizinhança, a ampliação da política de inclusão a leste e a sul (...), é incentivo bastante para promover a reforma democrática, suficientemente apetecível para ser um projecto comum da esmagadora maioria dos ucranianos (...), questão a prazo das potencialidades e dos limites da política de vizinhança.

A UE não conquista, atrai, como um império pós-moderno, na opinião de alguns analistas políticos, não impõe as suas leis aos outros, é quem se candidata que tem de aceitar o que existe, funciona como um império cooperativo. O segredo para estabilizar ou modernizar as caóticas periferias está na sua força de atracção, e nas perspectivas de uma futura adesão, a médio ou longo prazo. É alimentando-as que a UE molda as políticas e economias das nações e povos, ao longo das suas fronteiras em expansão, como na Turquia e na Ucrânia, releva J. Almeida Fernandes (Público, 12 de Dezembro 2004).

Já antes, a propósito da Ucrânia, escrevera: Há evidentemente dois desígnios geopolíticos em confronto. Para os estrategas americanos, a integração da Ucrânia na UE e na NATO é uma necessidade para impedir a reconstituição de um império russo na Europa e desarticular a sua hegemonia no Cáucaso e na Ásia Central (...). O Kremlin vê a expansão da UE e da NATO como um cerco e tem os seus próprios objectivos (...), substituir a antiga União Soviética por uma nova união encabeçada pela Rússia (...). Em Kiev, a escolha é entre democracia e autoritarismo (...). À Rússia (...) resta-lhe a ameaça de secessão do leste (...). País dividido, com uma forte minoria russófona e que incorpora territórios que foram historicamente russos, a Ucrânia tem de escolher simultaneamente o Ocidente e a Rússia (...). Por isso alguns vão mais longe e acrescentam que a UE deve responder agora à Ucrânia e dizer-lhe que há um lugar para ela na Europa (Público, 5 de Dezembro 2004). 
Outros analistas políticos acentuam que é preciso encarar a questão de uma Europa de geometria variável, de saber se a Europa está preparada para ser uma entidade euro-médio-oriental, tratar a questão curda, assumir responsabilidade no Cáucaso, ter um papel importante no Médio Oriente, sem esquecer o Norte de África.

\section{AGRADECIMENTOS}

Estudo integrado no Projecto Repensar Portugal na Europa. Perspectivas de um país periférico, PRAXIS, FCT. Agradeço a Carlos Alberto Medeiros a leitura atenta e crítica do manuscrito, as correcções introduzidas e todas as sugestões de melhoria do texto, que foi inserido em CaVACO (2004).

\section{BIBLIOGRAFIA}

Barrot, J.; Elissalde, B. e Rogues, G. (2002) - Europe. Espaces en recomposition. Vuibert, Paris.

Béroud, S. et Weydert, J. (1997) - Le devenir de l'Europe. Les Éditions de l'Atelier/Éditions Ouvrières, Paris.

Carroué, L. (2002) - Géographie de la Mondialisation. Armand Colin, Paris.

CAvaco, C. (2004) - Repensar Portugal na Europa. Um quadro alargado e global. EPRU, 59, CEG, Lisboa.

CArroué, L. (2001) - L'Union Européenne. De l'Union Européenne à l'Europe occidentale. Armand Colin, Paris.

DuchêNe, F. (1985) - La Communauté Européenne et le bassin méditerranéen. Documentation Européenne, Bruxelas.

Fontoura, M. P. e Crespo, N. (org.) (2004) - O alargamento da União Europeia. Consequências para a Economia Portuguesa. Económicas, Celta Editora, Oeiras.

Foucher, M. (1998) - La République européenne. Entre histoires et géographies. Éditions Belin, Paris.

GonZÁLEZ, J. R. e DAsí, J. F. (2004) - Ordenación del território y desarrollo territorial. Il gobierno del território en Europa: tradiciones, contextos, culturas $Y$ nuevas visiones. Ediciones Trea, S. L., Madrid.

Huntington, S. P. (2001) - O Choque de Civilizações e a Mudança na Ordem Mundial. Gradiva, Lisboa.

LÉvY, J. (1997) - Europe. Une géographie. Hachette Livre, Paris.

Maurel, M.-C. et al. (2003) - Le Repli Paysan. Trajectoires de l'après communisme en Pologne. L'Harmattan, Paris.

Romão, A. (org.) (2004) - Economia Europeia. Económicas, Celta Editora, Oeiras.

S/Autor (1993) - Croissance, Compétitivité, Emploi. Les défis et les pistes pour entrer dans le XXI siècle. Livre blanc. Comissão Europeia, Bruxelas.

S/Autor (2002) - Polónia. Seu parceiro económico, 2002-2003. Instituto de Conjunturas e Preços do Comércio Exterior, Varsóvia.

VÁrIos (1991) - Geografia Universal. vols. 2 e 3. Resomnia Editores, Barcelona. 